\title{
Introducing Statistics within a Gender Focal Point Strategy
}

\author{
Fred Spiring \\ Bureau of Women's Affairs \\ Office of the Prime Minister
}

\begin{abstract}
The United Nations Development Strategy for Gender in Development Programme [1] relies heavily on two key components. The first is the strategy or problem solving technique often referred to as the Plan-Do-Check-Act (PDCA) cycle (or the PLANNING AND REVIEW CYCLES IMPLEMENTATION) and the second the Gender Focal Points. The PDCA cycle is a mechanism for planning, documenting, analyzing, implementing and verifying the impact of a plan or strategy and the GFPs are the resources critical to the implementation of the PDCA. This manuscript a) outlines the key components of the PDCA cycle along with tools associated with each of the four stages in the cycle and b) provides a gender based approach to integrating the concepts of statistics into the Gender Focal Point training regimen. A series of ten modules, each taking less than 120 minutes to present, have been developed using Microsoft Office's [2] PowerPoint, Word and Excel. The ten modules were developed in conjunction with, and for use by, the Bureau of Women's Affairs, Office of the Prime Minister, Government of Jamaica. The PowerPoint presentations, related datasets, questionnaires and supporting material are available from the author.
\end{abstract}

Keywords: Gender Mainstreaming, Gender Training, Performance Indicators

\section{INTRODUCTION}

The Bureau of Women's Affairs (BWA) is a department in the Office of the Prime Minister that has been a Jamaican Government entity for more than 35 years. The current mission of the BWA is "To enable women to achieve their full potential as participants in Jamaica's social, cultural and economic development and with equitable access to benefits from the country's resources". The BWA seeks to carry out this objective through Policy Development, Analysis, Research, Documentation, Project Planning, Monitoring, Public Education and Community Outreach.

The Policy and Research Unit is responsible for the policy and research agenda of the BWA. The department consists of two sections, a) Policy and b) Research \& Documentation. The main purpose of the Policy section is the development, formulation and analysis of policies to enhance the status of women economically, socially and politically. This is to ensure that gender considerations are taken into account, that the gender international agreements signed and ratified by the Government of Jamaica are adhered to and emphasis is placed on gender equality while highlighting the gaps where they exist. In order to do this, the BWA ensures that national policies relating to women and men are implemented in accordance with guidelines, monitored and evaluated in order to achieve the desired objectives. Additionally, the Policy section is responsible for reviewing other government policies for gender considerations. Arising from this, recommendations are made for the inclusion of a gendered component in these policies. The legislative agenda also forms a part of the policy portfolio. 
In keeping with the Strategic/Operational Plan, the BWA conducts gender-specific research in order to gather empirical data in support of policy decisions relating to women and men. The specific and general objectives of the national women's machinery (NWM), the principles outlined in the National Policy Statement on Women and the National Policy for Gender Equality (NPGE) [3] as well as local, regional and international policy commitments all form part of the BWA's mandate.

Figure 1 contains relevant Targets/Objectives of the NPGE addressed by the training strategy and regimen. In particular the Targets/Objectives "To make the collection of data disaggregated by sex and location mandatory by all public and private agencies in the social, economic and political sectors on a regular and timely basis", "To set up systems to facilitate ready retrieval of these data as required by researchers, planners and policy-makers", "To produce a comprehensive manual of gender indicators related to all major sectors which can be used to inform of plans, projects, and programmes and for monitoring their impact" and "To equip all persons involved in planning and policy formulation with the tools for conducting gender analyses and the skills to use the information produced to develop, monitor and evaluate projects, programmes and policies" are addressed in whole or in part by the training.

The strategy involves consultative approaches that include representatives from the various Ministries, Departments and Agencies (MDAs) of the Jamaican Government through Gender Focal Points (GFPs). The GFPs are persons who represent their MDA in the Gender and Gender Mainstreaming initiative conducted by the BWA and The Way Out Project. The GFPs are exposed to a series of workshops designed to raise awareness and to sensitize the MDAs to gender and gender mainstreaming. The GFP approach to integrating Gender and Gender Mainstreaming is the approach promoted by the United Nations Development Programme for Gender in Development Programme [1]. The BWA has introduced Gender and Gender Mainstreaming, through the GFPs, to more than sixty MDAs since 2010 and is now preparing to provide statistical training and support to these groups. This manuscript outlines the training strategy, initiatives and materials developed in an attempt to integrate "statistical thinking" to the GFP strategy.

National Policy on Gender Equality Objectives Addressed

\begin{tabular}{|c|c|c|c|c|c|}
\hline \multicolumn{6}{|c|}{ Gender Mainstreaming } \\
\hline Target/Objective & Strategy/Indicator & $\begin{array}{l}\text { Responsible } \\
\text { Institution }\end{array}$ & Resources & $\begin{array}{l}\text { Time } \\
\text { Frame }\end{array}$ & Actions \\
\hline $\begin{array}{l}\text { To make the collection } \\
\text { of data disaggregated by } \\
\text { sex and location } \\
\text { mandatory by all public } \\
\text { and private agencies in } \\
\text { the social, economic } \\
\text { and political sectors on } \\
\text { a regular and timely } \\
\text { basis }\end{array}$ & $\begin{array}{l}\text { Annual data sets } \\
\text { produced on } \\
\text { indicators relevant to } \\
\text { the mandate and work } \\
\text { of the particular } \\
\text { agency }\end{array}$ & $\begin{array}{l}\text { BWA, } \\
\text { STATIN, } \\
\text { PIOJ, Electoral } \\
\text { Office of } \\
\text { Jamaica. All } \\
\text { government } \\
\text { agencies } \\
\text { statistical } \\
\text { departments. } \\
\text { All private } \\
\text { sector bodies }\end{array}$ & $\begin{array}{l}\text { Statistician at } \\
\text { the BWA and } \\
\text { Focal Point at } \\
\text { STATIN }\end{array}$ & $\begin{array}{l}2011- \\
2015\end{array}$ & $\begin{array}{l}\text { BWA } \\
\text { Technical } \\
\text { Report: } \\
\text { Introducing } \\
\text { Statistics } \\
\text { within a } \\
\text { Gender Focal } \\
\text { Point } \\
\text { Strategy, } \\
\text { Investigating } \\
\text { Gender } \\
\text { Violence In } \\
\text { Jamaica } \\
\text { 2007-2012 }\end{array}$ \\
\hline
\end{tabular}




\begin{tabular}{|c|c|c|c|c|c|}
\hline $\begin{array}{l}\text { To set up systems to } \\
\text { facilitate ready retrieval } \\
\text { of these data as required } \\
\text { by researchers, planners } \\
\text { and policy-makers. }\end{array}$ & $\begin{array}{l}\text { Data used by relevant } \\
\text { stakeholders and as } \\
\text { the basis for gender } \\
\text { responsive planning } \\
\text { and policy } \\
\text { formulation by the } \\
\text { respective agencies }\end{array}$ & $\begin{array}{l}\text { BWA/STATIN } \\
\text { and } \\
\text { partnership } \\
\text { with IDPs }\end{array}$ & $\begin{array}{l}\text { Funds to } \\
\text { conduct } \\
\text { training in } \\
\text { gender analysis } \\
\text { and policy } \\
\text { formulation }\end{array}$ & $\begin{array}{l}2011- \\
2015\end{array}$ & $\begin{array}{l}\text { BWA } \\
\text { Technical } \\
\text { Report: The } \\
\text { Gender } \\
\text { Equality } \\
\text { Observatory } \\
\text { of Jamaica }\end{array}$ \\
\hline $\begin{array}{l}\text { To equip all persons } \\
\text { involved in planning } \\
\text { and policy formulation } \\
\text { with the tools for } \\
\text { conducting gender } \\
\text { analyses and the skills } \\
\text { to use the information } \\
\text { produced to develop, } \\
\text { monitor and evaluate } \\
\text { projects, programmes } \\
\text { and policies }\end{array}$ & $\begin{array}{l}\text { Training programme } \\
\text { a) developed and } \\
\text { offered to relevant } \\
\text { stakeholders and b) } \\
\text { assessed in terms of } \\
\text { impact and } \\
\text { effectiveness }\end{array}$ & $\begin{array}{l}\text { BWA, } \\
\text { CGDS/UWI, } \\
\text { PIOJ }\end{array}$ & $\begin{array}{lr}\text { Funding } & \text { to } \\
\text { support } & \\
\text { delivery } & \text { and } \\
\text { evaluation } & \text { of } \\
\text { impact } & \text { of } \\
\text { training } & \end{array}$ & $\begin{array}{l}2012- \\
2015\end{array}$ & $\begin{array}{l}\text { BWA } \\
\text { Technical } \\
\text { Report: } \\
\text { Introducing } \\
\text { Statistics } \\
\text { within a } \\
\text { Gender Focal } \\
\text { Point Strategy }\end{array}$ \\
\hline $\begin{array}{l}\text { To produce a } \\
\text { comprehensive manual } \\
\text { of gender indicators } \\
\text { related to all major } \\
\text { sectors which can be } \\
\text { used to inform policy, } \\
\text { programmes, plans, and } \\
\text { projects and for } \\
\text { monitoring their impact }\end{array}$ & $\begin{array}{l}\text { Gender Indicators } \\
\text { Manual developed by } \\
\text { reviewing indicators } \\
\text { produced by BWA, } \\
\text { CARICOM, ECLAC, } \\
\text { JASPEV, PIOJ \& } \\
\text { OPM checklists and } \\
\text { Gender Indicators } \\
\text { produced by UN } \\
\text { (GEM and GDI) in } \\
\text { order to compile a } \\
\text { composite checklist } \\
\text { for monitoring impact } \\
\text { of programmes in all } \\
\text { sectors }\end{array}$ & $\begin{array}{l}\text { BWA, } \\
\text { STATIN, } \\
\text { PIOJ, } \\
\text { CGDS/UWI, } \\
\text { and IDP } \\
\text { partnership }\end{array}$ & $\begin{array}{l}\text { Funds to } \\
\text { acquire } \\
\text { relevant } \\
\text { software and } \\
\text { programming } \\
\text { and Technical } \\
\text { Assistance } \\
\text { from regional } \\
\text { and international } \\
\text { bodies/IDP } \\
\text { partnership }\end{array}$ & $\begin{array}{l}2011- \\
2012\end{array}$ & $\begin{array}{l}\text { BWA } \\
\text { Technical } \\
\text { Report: The } \\
\text { Gender } \\
\text { Equality } \\
\text { Observatory } \\
\text { of Jamaica, } \\
\text { DART } \\
\text { Module 5- } \\
\text { Performance } \\
\text { Indicators }\end{array}$ \\
\hline
\end{tabular}

Figure 1. NPGE Targets/Objectives addressed by BWA Training Modules

\section{Dart: why does data need to be accurate, relevant and timely?}

If your Data is Accurate, Relevant and Timely (DART), the likelihood of answering or meeting the goals of your study will be enhanced. Or in other words, the project, as well as the questions that the project is trying to address, will be more likely to be On-Target (Figure 2).
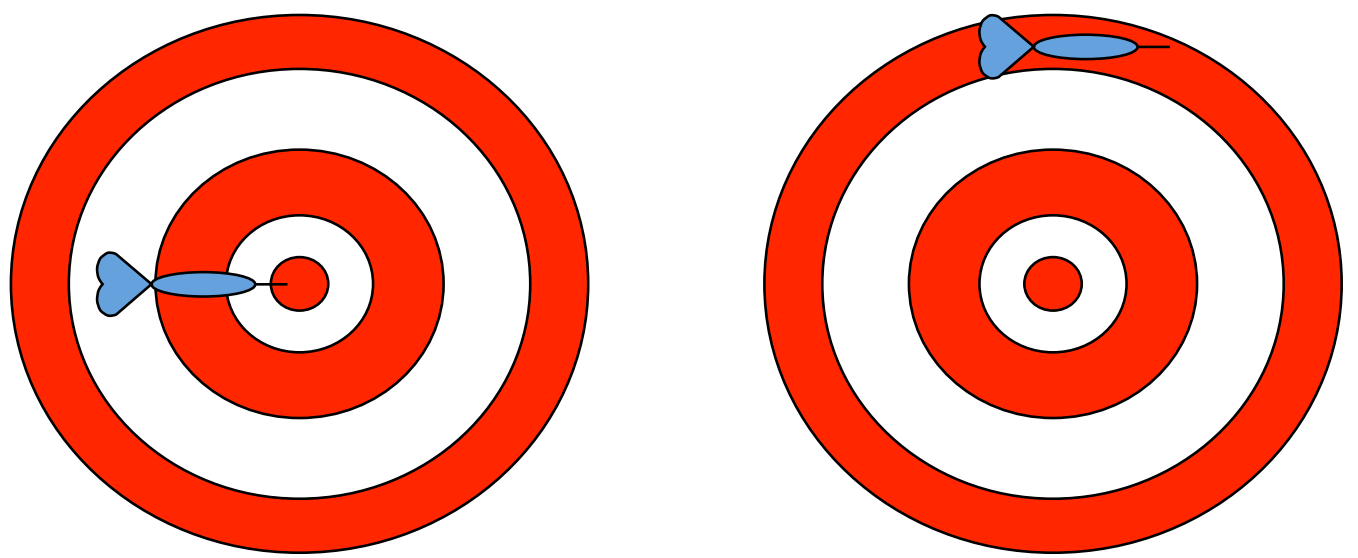

Figure 2. On-Target versus Off-Target

If the Accuracy or Relevance of the Data is lacking or questionable, the resulting statistics may be Off-Target (Figure 2) and will cause the project or study to be questioned. 
Consider a survey designed to examine an issue, where the survey designer failed to record the "sex" of the participants (see Figure 3). Certainly the data would be viewed as less Relevant, than if the sex of all participants had been recorded (sex disaggregated data). The lack of sex disaggregation virtually makes it impossible to perform any meaningful Gender analyses and causing DART to be far from the target.

Similarly, if the Accuracy of the survey or data gathering is inconsistent, the statistics and resulting conclusions or recommendations will likely be "off-target" or more variable. In a fast changing world, Timeliness is always important. Attempting to develop and make policy decisions based on Data that is not timely, or is out-of-date, will only serve to cast doubt on the outcomes and the resulting recommendations. Stale or old Data may also provide "fuel" for detractors of the project or study.

Gnirips Shoe Company

Survey \# 1

Name: Fred

Shoe Size: $\_\underline{9.5}$

Gnirips Shoe Company Survey \# 2

Name:_Dawn

Shoe Size: $\quad 6.5$

Gnirips Shoe Company

Survey \# 3

Name:_Oahn

Shoe Size: $\_40$

Gnirips Shoe Company

Survey \# 4

Name:_Lee

Shoe Size: $\quad 7.0$

Gnirips Shoe Company

Survey \# 5

Name: Terry

Shoe Size: __

Gnirips Shoe Company Survey \# 6

Name:_Chris

Shoe Size: ___ 11.0

Gnirips Shoe Company

Survey \# 7

Name:_Eddi

Shoe Size: $\quad$ _ 9.5
Gnirips Shoe Company

Survey \# 8

Name: Melissa

Shoe Size: __

Gnirips Shoe Company

Survey \# 9

Name:_Jamie

Shoe Size: 8.0

Gnirips Shoe Company

Survey \# 10

Name:

Shoe Size: $\quad 9.0$

Gnirips Shoe Company

Survey \# 11

Name:_Narula

Shoe Size: ___ 13

Gnirips Shoe Company

Survey \# 12

Name:_Dominic

Shoe Size: $\_\_$_

Gnirips Shoe Company

Survey \# 13

Name:_Anne

Shoe Size: $\quad 6.5$

Gnirips Shoe Company

Survey \# 14

Name:_Charlie

Shoe Size: 11.0
Gnirips Shoe Company

Survey \# 15

Name: _Britta

Shoe Size: ___

Gnirips Shoe Company

Survey \# 16

Name:_Erika

Shoe Size: $\quad 6.0$

Gnirips Shoe Company

Survey \# 17

Name: Kathi

Shoe Size: $\quad 5.0$

Gnirips Shoe Company Survey \# 18

Name:__Toni

Shoe Size: __ 10.5

Gnirips Shoe Company Survey \# 19

Name: Aziz

Shoe Size: $\_$- 9.5

Gnirips Shoe Company Survey \# 20

Name:_Dhalia

Shoe Size:

Gnirips Shoe Company

Survey \# 21

Name:__ Neptune

Shoe Size: 47

Figure 3. Initial Gnirips Shoe Size Survey Results 
The training has been designed to assist in ensuring that one's Data is Accurate, Relevant \& Timely. The ten DART modules address a variety of issues that should be considered before gathering/assessing data and implementing a strategy or plan. DART modules 1-6 deal directly with data and data issues. Each of these six DART modules has been designed to be presented in a 2 hour window and are incremental. DART modules 7-10 are designed to assist in systematically developing, implementing, verifying and adopting a strategy or plan. Again each of the DART modules has been designed to be presented in a 2 hour window (or less) and is incremental. DART modules 1 through 6 are used to introduce and motivate thought with respect to gathering, analyzing and interpreting data while DART modules 7 through 10 will be of assistance in developing, implementing and monitoring the GFP's Action Plan for promoting Gender and Gender Mainstreaming within their respective MDA.

\section{THE TRAINING-Strategy}

The modules have been constructed to introduce the concepts of statistics and their use in collecting, analyzing, displaying and interpreting data. This is done with the use of supporting information from various sources including gender based performance indicators (PIs). The training has been designed to challenge the participants with respect to issues that may impact any aspect of the data, rather than attempt to formally train in the field of statistics.

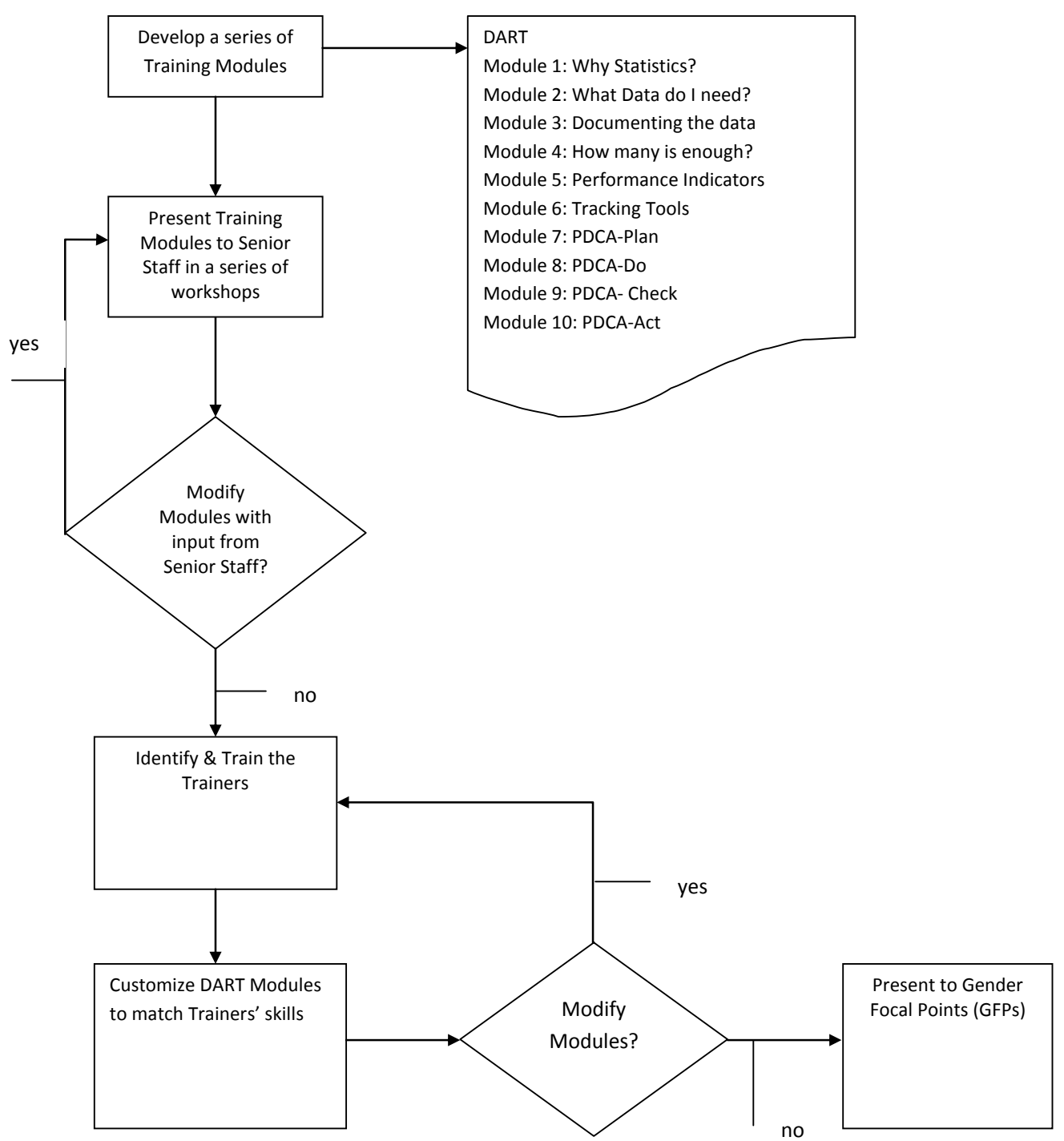

Figure 4. Training Strategy Flowchart 
The training strategy is three fold. The first stage (see Figure 4) involves introducing senior management to the DART training modules. The goals of these sessions are a) to raise awareness among the group, b) allow input and customization of the DART modules and c) to identify future trainers. The second stage of training involves the set of identified "trainers" from Stage 1. The goals of the second stage training include a) raise awareness among the group of trainers and b) customize the DART modules to the trainers' needs and strengths. The third stage sees the DART modules presented to all members of the group and to the GFPs as they identify the need to acquire and analyze data. The third stage also sees those trainers from stage two integrated into the training procedures as their comfort levels see fit.

The above strategy was designed to align with both CUSO International's and the BWA's focus on capacity building/technology transfer. Three strategic Objectives in the NPGE (see Figure 1) are addressed by the DART Training, they include 1) To make the collection of data disaggregated by sex and location mandatory by all public and private sector agencies in the social, economic and political sectors on a regular and timely basis, 2) To equip all persons involved in planning and policy formulation with the tools for conducting gender analyses and the skills to use the information produced to develop, monitor and evaluate projects, programmes and policies and 3) To produce a comprehensive manual of gender indicators related to all major sectors which can be used to inform policy, programmes, plans, and projects and for monitoring their impact are addressed directly by the training strategy and contents of the DART Modules.

Stages one and two of the strategy deal specifically with capacity building within the BWA, while Stage three sees capacity building extended to the GFPs of the various MDAs associated with the Government of Jamaica. Stages one and two were delivered by the CUSO International resource person, while Stage three saw the integration of BWA personnel, who have attended the Train the Trainer sessions, in the delivery of the DART Modules. For larger MDAs, in-house DART "Train the Trainer" sessions customized to their operations are offered.

\section{THE TRAINING-MODULES}

The DART modules have been developed in a fashion that illustrates basic concepts without "teaching statistics". Tables 1, 2 and 3 contain the list of DART module titles, training aids, intended audience, duration and training goals. 
Table 1. DART Modules 1 - 3 descriptions, duration and goals

\begin{tabular}{|c|c|c|c|c|}
\hline ITEM & ACTIVITIES/RESOURCES & WHO & \begin{tabular}{|l} 
WHE \\
$\mathrm{N}$ \\
\end{tabular} & EXPECTED OUTCOMES \\
\hline $\begin{array}{l}\text { DART- } \\
\text { Module } 1\end{array}$ & $\begin{array}{l}\text { Why Statistics? } \\
\text { - An overview of DART, a } \\
\text { discussion some simple } \\
\text { techniques and tools for } \\
\text { establishing Baseline measures to } \\
\text { assist in getting Gender Focal } \\
\text { Points (GFPs) started in gathering } \\
\text { information \& preparing baseline } \\
\text { statistics. } \\
\text { Medium: PowerPoint DART- } \\
\text { Module1 } \\
\text { Supporting Documents: 1) } \\
\text { Laminated sheets (x4) outlining } \\
\text { Gnirips Shoe Company Survey, 2) } \\
\text { TED Talk Video, 3) Gnirips Shoe } \\
\text { Survey Form, 4) Excel files: GFP } \\
\text { BaselineMeasures-Final -BWA, } \\
\text { GFP BaselineMeasures-Final, 5) } \\
\text { Word Document: } \\
\text { GenderSelfAssessment } \\
\text { Questionnaire }\end{array}$ & $\begin{array}{l}\text { Gender } \\
\text { Focal } \\
\text { Points }\end{array}$ & $\begin{array}{l}\text { Duration: } \\
120 \text { minutes }\end{array}$ & $\begin{array}{l}\text { Training Goals: 1) Stress the need for } \\
\text { Data that is Accurate, Relevant and } \\
\text { Timely, 2) Illustrate why anecdotal } \\
\text { evidence is a problem, 3) show how } \\
\text { statistics essentially amasses a number of } \\
\text { single stories in order to get a good } \\
\text { representation of the group being } \\
\text { studied, 4) discuss the impact on studies, } \\
\text { research and policy if the data is not } \\
\text { accurate, relevant or timely, 5) provide } \\
\text { simple straightforward tools to get } \\
\text { started gathering and presenting baseline } \\
\text { data }\end{array}$ \\
\hline $\begin{array}{c}\text { DART } \\
\text { Module } 2\end{array}$ & $\begin{array}{l}\text { What Data do I Need? } \\
\text { - Medium: PowerPoint DART- } \\
\text { Module2 } \\
\text { - Supporting Documents: 1) Animal } \\
\text { crackers (1 package for each } \\
\text { participant) and 2) Christie Canada } \\
\text { Cracker surveys and tally sheet. }\end{array}$ & $\begin{array}{l}\text { Gender } \\
\text { Focal } \\
\text { Points }\end{array}$ & $\begin{array}{l}\text { Duration: } \\
90 \text { minutes }\end{array}$ & $\begin{array}{l}\text { Training Goals: 1) Continue to reinforce } \\
\text { the need for Data that is Accurate, } \\
\text { Relevant and Timely, 2) illustrate the } \\
\text { need and difficulty in determining what } \\
\text { data needs to be collected, 3) illustrate } \\
\text { that in order for the data to be relevant it } \\
\text { must address the goal(s) of the } \\
\text { study/research and 4) conduct a brain } \\
\text { storming session on a particular } \\
\text { Performance Indicator. }\end{array}$ \\
\hline $\begin{array}{c}\text { DART } \\
\text { Module } 3\end{array}$ & $\begin{array}{l}\text { Documenting the Data } \\
\text { - Medium: PowerPoint DART- } \\
\text { Module3, IHSN Metadata Editor \& } \\
\text { Nesstar Explorer } \\
\text { - Supporting Documents: 1) Gnirips } \\
\text { Shoe Survey Metadata sheet, 2) } \\
\text { Gnirips Shoe Survey data } \\
\text { acquisition sheet, 3) Conversion } \\
\text { chart and 4) Animal Cracker Data } \\
\text { sheet }\end{array}$ & $\begin{array}{l}\text { Gender } \\
\text { Focal } \\
\text { Points }\end{array}$ & $\begin{array}{l}\text { Duration: } \\
120 \text { minutes }\end{array}$ & $\begin{array}{l}\text { Training Goals: 1) Continue to reinforce } \\
\text { the need for Data that is Accurate, } \\
\text { Relevant and Timely, 2) illustrate the } \\
\text { need to document the data before it is } \\
\text { collected, 3) illustrate the use of the } \\
\text { IHSN software and 4) the delivery of } \\
\text { usable, well defined data sheets that will } \\
\text { allow JMP (or other software) analyses. }\end{array}$ \\
\hline
\end{tabular}


Table 2. Dart Modules 4 - 8 descriptions, duration and goals

\begin{tabular}{|c|c|c|c|c|}
\hline ITEM & ACTIVITIES/RESOURCES & WHO & WHEN & EXPECTED OUTCOMES \\
\hline $\begin{array}{c}\text { DART } \\
\text { Module } 4\end{array}$ & $\begin{array}{l}\text { How many is enough? } \\
\text { - Medium: PowerPoint DART- } \\
\text { Module4 } \\
\text { Supporting Documents: 1) Gnirips } \\
\text { Shoe Survey data sheet, 2) Return } \\
\text { to the Single Story and ask how } \\
\text { many stories does one need to be } \\
\text { relevant, 3) ensure measuring } \\
\text { device is not introducing errors, } \\
\text { Gnirips straws \& measuring devices }\end{array}$ & $\begin{array}{l}\text { Gender } \\
\text { Focal } \\
\text { Points }\end{array}$ & $\begin{array}{l}\text { Duration: } \\
120 \text { minutes }\end{array}$ & $\begin{array}{l}\text { Training Goals: 1) Continue to reinforce } \\
\text { the need for Data that is Accurate, } \\
\text { Relevant and Timely, 2) illustrate the } \\
\text { need to assess how many samples need } \\
\text { be taken, 3) provide some ideas as to } \\
\text { what might influence "how many/often" } \\
\text { and 4) illustrate the need for a good } \\
\text { measuring device and recording } \\
\text { mechanism. }\end{array}$ \\
\hline $\begin{array}{c}\text { DART } \\
\text { Module } 5\end{array}$ & $\begin{array}{l}\text { Performance Indicators } \\
\text { - Duration: } 120 \text { minutes } \\
\text { Medium: PowerPoint DART- } \\
\text { Module5, Supporting Documents: } \\
\text { 1)Physical Violence datasheet, 2) } \\
\text { MonthlyMurders.JMP and 3) } \\
\text { MajorCrimes.JMP }\end{array}$ & $\begin{array}{l}\text { Gender } \\
\text { Focal } \\
\text { Points }\end{array}$ & $\begin{array}{l}\text { Duration: } \\
120 \text { minutes }\end{array}$ & $\begin{array}{l}\text { Training Goals: 1) Continue to reinforce } \\
\text { the need for Data that is Accurate, } \\
\text { Relevant and Timely, 2)using the Gender } \\
\text { Equality Observatory goals to illustrate } \\
\text { Performance Indicators, 3) illustrate } \\
\text { need to have a baseline set of measures } \\
\text { in order to monitor over time, 4) } \\
\text { develop long term tracking tools to } \\
\text { signal change and 5) illustrate Excel } \\
\text { plotting techniques. }\end{array}$ \\
\hline $\begin{array}{c}\text { DART } \\
\text { Module } 6\end{array}$ & $\begin{array}{l}\text { Tracking Tools } \\
\text { Medium: PowerPoint DART- } \\
\text { Module6, Supporting Documents: } \\
\text { 1) ShoeSize example, 2) Rape-JCF- } \\
\text { 2007-2011, 3) RapeDataxxx.JMP } \\
\text { and 4) AlcoholDeathsxxx.JMP }\end{array}$ & $\begin{array}{l}\text { Gender } \\
\text { Focal } \\
\text { Points }\end{array}$ & $\begin{array}{l}\text { Duration: } \\
120 \text { minutes }\end{array}$ & $\begin{array}{l}\text { Training Goals: 1) Continue to reinforce } \\
\text { the need for Data that is Accurate, } \\
\text { Relevant and Timely, 2) illustrate need } \\
\text { to have a baseline set of measures in } \\
\text { order to monitor over time, } 3 \text { ) develop } \\
\text { long term tracking tools to signal } \\
\text { change. Introduce runs chart, control } \\
\text { chart and capability chart by adding } \\
\text { action limits to existing scatter plots and } \\
\text { 4) illustrate the use of JMP as an } \\
\text { analytical tool. }\end{array}$ \\
\hline $\begin{array}{c}\text { DART } \\
\text { Module } 7\end{array}$ & $\begin{array}{l}\text { PDCA-Plan } \\
\text { Medium: PowerPoint DART- } \\
\text { Module7, Supporting Documents: } \\
\text { 1) Respiratory Flowchart, 2) } \\
\text { laminated Gnirips Shoe Survey data } \\
\text { sheets, 3) F's and 4) Inspection } \\
\text { Bookmark }\end{array}$ & $\begin{array}{l}\text { Improve } \\
\text { ment \& } \\
\text { Problem } \\
\text { Solving } \\
\text { specialis } \\
\text { ts }\end{array}$ & $\begin{array}{l}\text { Duration: } \\
120 \text { minutes }\end{array}$ & $\begin{array}{l}\text { Training Goals: 1) Continue to reinforce } \\
\text { the need for Data that is Accurate, } \\
\text { Relevant and Timely, 2) introduce the } \\
\text { concept of a process, 3) outline the } \\
\text { customer/supplier role in a process, 4) } \\
\text { introduce Brainstorming, C\&E, Flow } \\
\text { and Planning charts as tools of the Plan } \\
\text { stage in PDCA and 5) introduce the DO } \\
\text { stage as the implementation stage. } \\
\text { Conduct a brainstorming session relevant } \\
\text { to the group. }\end{array}$ \\
\hline $\begin{array}{c}\text { DART } \\
\text { Module } 8\end{array}$ & $\begin{array}{l}\text { PDCA-Do } \\
\text { Medium: PowerPoint DART- } \\
\text { Module8, Supporting Documents: } \\
\text { 1) GEOJ Flowchart \& Milestones } \\
\text { and 2) GEOJ Planning document }\end{array}$ & $\begin{array}{l}\text { Improve } \\
\text { ment \& } \\
\text { Problem } \\
\text { Solving } \\
\text { specialis } \\
\text { ts }\end{array}$ & $\begin{array}{l}\text { Duration: } \\
30 \text { minutes }\end{array}$ & $\begin{array}{l}\text { Training Goals: 1) Continue to reinforce } \\
\text { the need for Data that is Accurate, } \\
\text { Relevant and Timely, 2) reinforce the } \\
\text { PDCA concept, 3) reinforce the } \\
\text { customer/supplier role in a process, 4) } \\
\text { implement the results of the } \\
\text { Brainstorming, C\&E, Flow and Planning } \\
\text { charts from the PDCA-Plan session 5) } \\
\text { discuss the DO stage as the } \\
\text { implementation stage }\end{array}$ \\
\hline
\end{tabular}


Table 3. DART Training Modules 9 \& 10 descriptions, duration and goals

\begin{tabular}{|c|c|c|c|c|}
\hline ITEM & ACTIVITIES/RESOURCE & WHO & WHEN & EXPECTED OUTCOMES \\
\hline $\begin{array}{c}\text { DART } \\
\text { Module } 9\end{array}$ & $\begin{array}{l}\text { PDCA-Check } \\
\text { Medium: PowerPoint DART- } \\
\text { Module9, Supporting } \\
\text { Documents: 1) Gnirips Shoe } \\
\text { Survey Check \& Tally sheet, } \\
\text { 2) Population Figures by } \\
\text { Parish for Jamaica, Pharmacy } \\
\text { patients by Parish, 3) Voter's } \\
\text { List 2007 vs. 2011 and 4) } \\
\text { Accident data from Winnipeg } \\
\end{array}$ & $\begin{array}{l}\text { Improvement } \\
\& \quad \text { Problem } \\
\text { Solving } \\
\text { specialists }\end{array}$ & $\begin{array}{l}\text { Duration: } \\
90 \text { minutes }\end{array}$ & $\begin{array}{l}\text { Training Goals: 1) Continue to } \\
\text { reinforce the need for Data that is } \\
\text { Accurate, Relevant and Timely, 2) } \\
\text { introduce the Check \& Tally sheet, } \\
\text { 3) introduce the bar chart, 4) } \\
\text { introduce the Pareto chart, discuss } \\
\text { various Scatter plots and 5) highlight } \\
\text { Location charts as tools of the Check } \\
\text { stage in PDCA cycle. }\end{array}$ \\
\hline $\begin{array}{c}\text { DART } \\
\text { Module } 10\end{array}$ & $\begin{array}{l}\text { PDCA-Act } \\
\text { Medium: PowerPoint DART- } \\
\text { Module10, Supporting } \\
\text { Documents: 1) Drunk Driving } \\
\text { Laws-Gleaner, 2) Bill 3- } \\
\text { Winnipeg }\end{array}$ & $\begin{array}{l}\text { Improvement } \\
\& \quad \text { Problem } \\
\text { Solving } \\
\text { specialists }\end{array}$ & $\begin{array}{l}\text { Duration: } \\
120 \text { minutes }\end{array}$ & $\begin{array}{l}\text { Training Goals: 1) Continue to } \\
\text { reinforce the need for Data that is } \\
\text { Accurate, Relevant and Timely, 2) } \\
\text { introduce/review runs chart, control } \\
\text { chart and capability chart by adding } \\
\text { action limits to existing scatter plots, } \\
\text { 3) illustrate need to have a baseline } \\
\text { set of measures in order to monitor } \\
\text { over time, 4) develop long term } \\
\text { tracking tools to signal change and 5) } \\
\text { in a continuous improvement } \\
\text { environment one starts the PDCA } \\
\text { cycle again. Tie these tools back into } \\
\text { Modules 5 \& } 6 \text {. }\end{array}$ \\
\hline
\end{tabular}

\section{DART Module 1}

\section{Bureau of Women's Affairs DART: Module 1}

WHY DO WE USE STATISTICS?

TO AVOID ANECDOTAL DATA INFLUENCING THE DECISION-MAKING PROCESS

- TO AVOID “SINGLE STORIES” FROM BECOMING THE NORMAL

TO ASSIST IN DART BEING ON-TARGET

DART Module 1 "Why Do We Use Statistics?" has been created to introduce DART and to motivate the need for incorporating statistics into a Gender Mainstreaming Action Plan. The Module includes instruments that facilitate the collection, analysis and display of data addressing a self-assessment of participants understanding of Gender and Gender Mainstreaming. The instrument is built in Excel and has been designed to be self-contained. Participants simply enter their self assessed level of knowledge (low, medium or high) for both 
Gender and Gender Mainstreaming, along with their respective sex female and male in the row associated with a survey number assigned to them. The instrument has been set-up to address groups of up to 50 participants complete with electronic copy of 50 numbered questionnaires that need only be printed and distributed and the automated frequency charts. Figures 5, 6, 7 \& 8 contain the a)questionnaire, b) Instructions, c) G \& GM Data Excel spread sheet and d) resulting charts for a group of participants attending a Quarterly meeting of the BWAs Gender Focal Points (June 28, 2012). All participants had been exposed to the BWA's Gender and Gender Mainstreaming training.

Gender Self-Assessment Questionnaire Example

Sex

Female Male

Please circle a level (Low, Medium or High) indicating your level of knowledge for the questions below.

What is your knowledge level of Gender?

Low Medium High

What is your knowledge level of Gender Mainstreaming?

Low Medium High

Gender Self-Assessment Questionnaire \#1

Sex

Female Male

Please circle a level (Low, Medium or High) indicating your level of knowledge for the questions below.

What is your knowledge level of Gender?

Low Medium High

What is your knowledge level of Gender Mainstreaming?

Low Medium High

Figure 5. Gender and Gender Mainstreaming Self Assessment Questionnaire Example \& \#1 Instructions:

1) Ask each Group member to complete a Self Assessment Questionnaire

2) There are 50 numbered questionnaires in the accompanying GenderSelfAssessmentQuestionnaire Word file

If you require more please contact the $B W A$

they will create numbered questionnaires to accommodate your group size

and reconfigure the $\boldsymbol{G} \& \boldsymbol{G M}$ Data sheet to accommodate your group size

3) Enter the Questionnaire responses in the Excel sheet named $\boldsymbol{G} \& \boldsymbol{G M}$ Data

for sex there are 3 valid responses female, male or "blank"

for Gender \& Gender Mainstreaming there are 4 valid responses

Low, Medium, High or "blank"

For the Gender Self-Assessment Questionnaire Example 
(top of the Questionnaire document)

the survey number is Example and the response is male

Low Low

4) All the counts and plots should update as you enter the data

Please keep the actual questionnaires

Very few of the cells in the $\boldsymbol{G} \& \boldsymbol{G M}$ Data sheet are

locked and can be altered

If something looks funny or if the $\boldsymbol{G} \& \boldsymbol{G M}$ Data sheet goes awry, DO NOT WORRY

Contact the Bureau, they can send another copy to you electronically

5) Please let the BWA know if you have any difficulties or encounter problems

Bureau of Women's Affairs

voice: $754-8576$

fax: 929-0549

Figure 6. Instructions for Gender \& Gender Mainstreaming Questionnaire

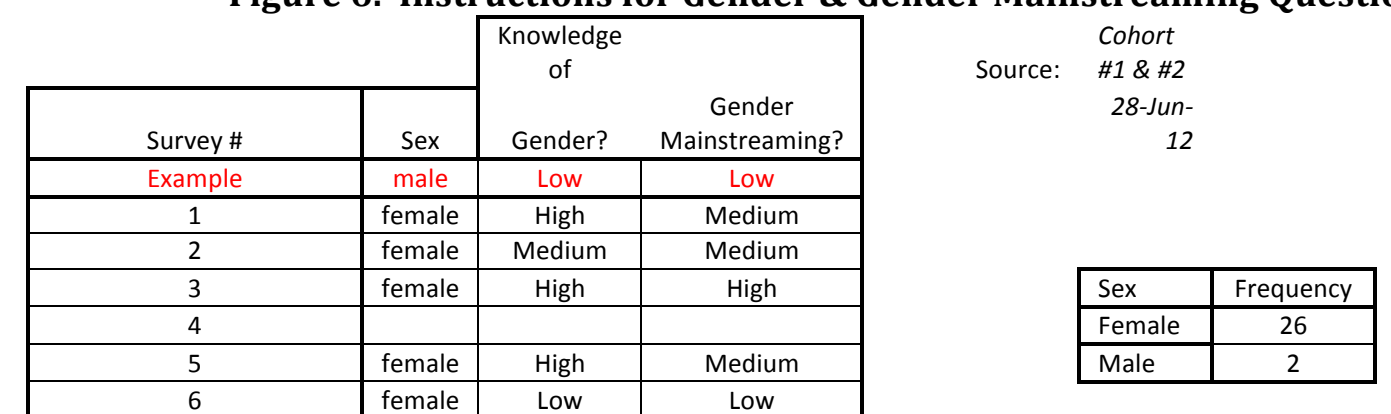

\begin{tabular}{|c|c|c|c|}
\hline 6 & female & Low & Low \\
\hline 7 & & & \\
\hline 8 & female & Medium & Medium \\
\hline 9 & female & Medium & Low \\
\hline 10 & & & \\
\hline 11 & & & \\
\hline 12 & female & Medium & Medium \\
\hline 13 & & & \\
\hline 14 & & & \\
\hline 15 & female & Medium & Low \\
\hline 16 & & & \\
\hline 17 & & & \\
\hline 18 & female & Medium & Medium \\
\hline 19 & & & \\
\hline 20 & & & \\
\hline 21 & male & Medium & Medium \\
\hline 22 & & & \\
\hline 23 & female & Medium & Medium \\
\hline 24 & female & High & High \\
\hline 25 & & & \\
\hline 26 & female & Medium & Medium \\
\hline 27 & & & \\
\hline 28 & & & \\
\hline 29 & female & Medium & Medium \\
\hline 30 & female & Medium & Medium \\
\hline 31 & & & \\
\hline 32 & female & Medium & Medium \\
\hline 33 & male & High & Medium \\
\hline 34 & & & \\
\hline 35 & female & Medium & Medium \\
\hline 36 & female & High & Medium \\
\hline 37 & & & \\
\hline 38 & female & Medium & Medium \\
\hline 39 & female & High & High \\
\hline 40 & & & \\
\hline
\end{tabular}

Frequency

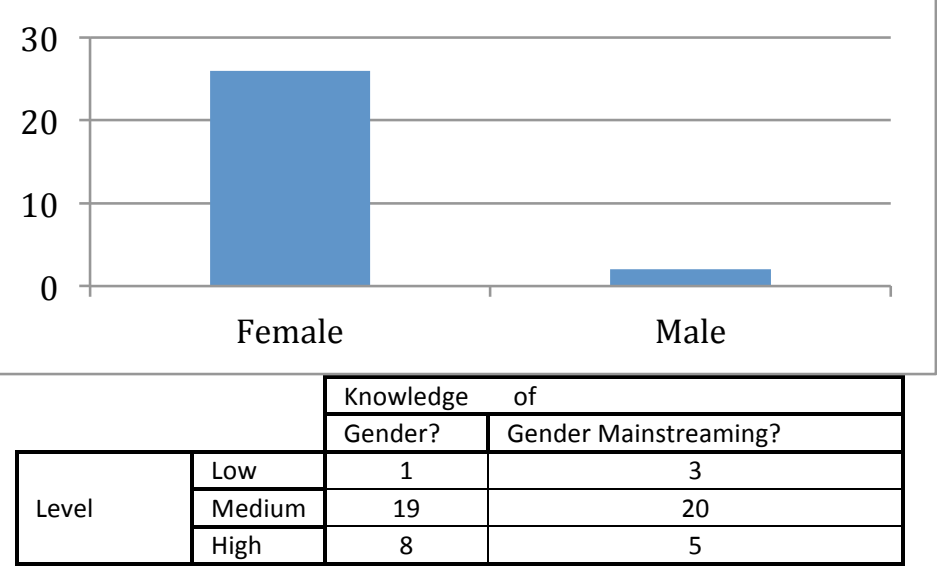




\begin{tabular}{|c|c|c|c|}
\hline 41 & & & \\
\hline 42 & female & Medium & High \\
\hline 43 & & & High \\
\hline 44 & female & High & \\
\hline 45 & & & \\
\hline 46 & & & Medium \\
\hline 47 & female & Medium & Medium \\
\hline 48 & female & Medium & Medium \\
\hline 49 & female & Medium & 28 \\
\hline 50 & female & Medium & \\
\hline Count & 28 & 28 & \\
Attendees & 39 & & \\
Returned/Completed & 25 & \\
Returned/Uncompleted & 10 & \\
Unreturned/Completed & 3 & \\
Unreturned/Uncompleted & 12 & \\
Non-Response rate: & $28 \%$ & & \\
\hline
\end{tabular}

Figure 7. G \& GM Data worksheet with data for June 28, 2012

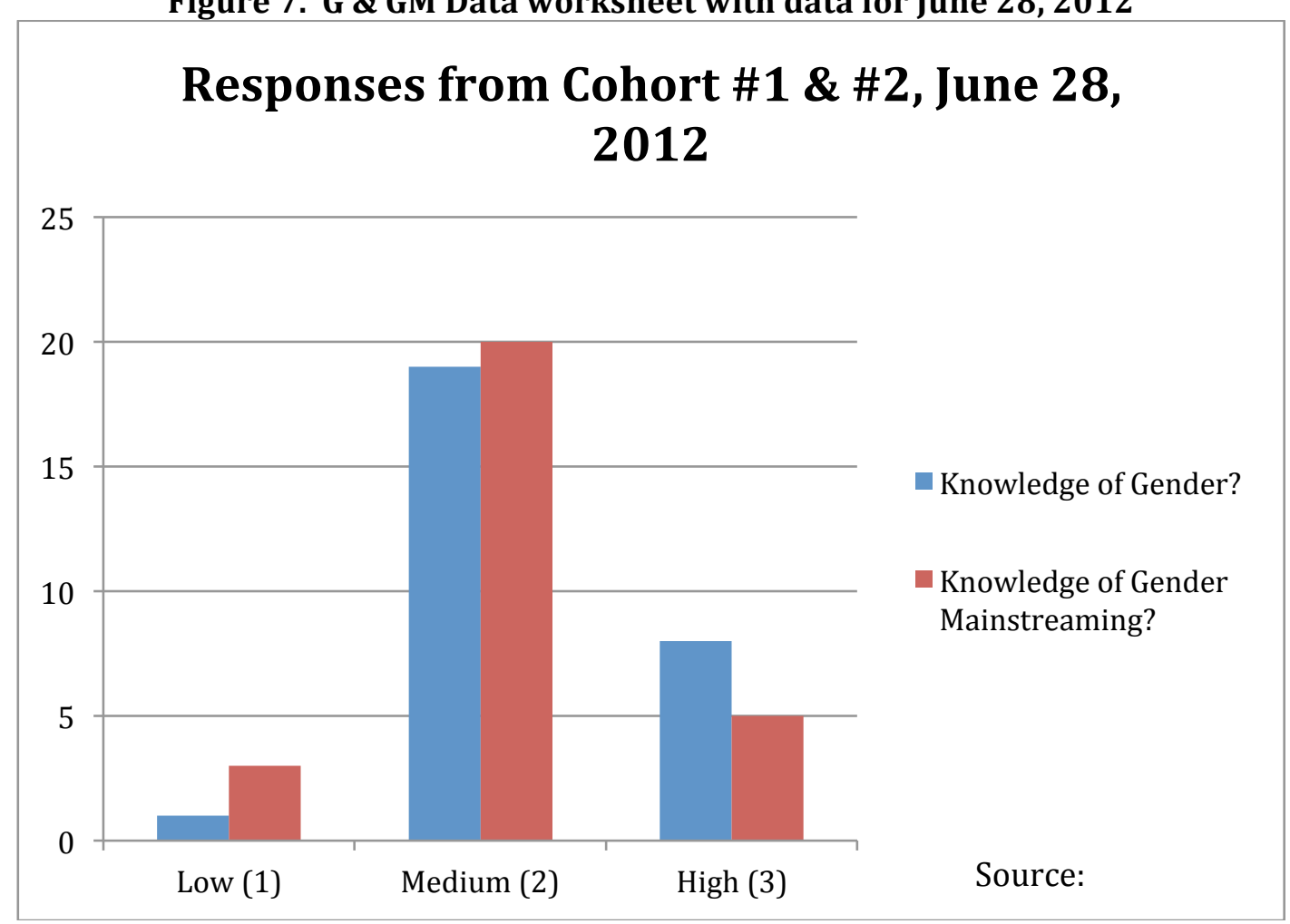

Figure 8. Frequencies for Gender and Gender Mainstreaming Self-Assessment June 28, 2012

A second instrument has been developed that addresses the frequency of Decision makers, Policy developers and Project managers within a group or organization. The basic requirement is a list of people in the group/organization and their respective responsibilities. The information is often readily available from a group's organizational chart. The database has been set up to include the name/identifier and sex of the people in the group/organization. Once this information has been entered, a series of six questions are asked (see Figure 10). "Is this person a Female Decision maker?" select "yes" or "no". Doing this for each of the six questions results in a profile score for each participant (see Figure 11 for a set of simulated responses). Figure 9 contains the instructions for completing the instrument.

A frequency chart of the responses is generated automatically (see Figure 11). The chart includes the frequency of females and males in the group/organization, the frequency of male and female Decision makers, Policy developers and Project managers along with the expected 
or statistical frequency based on the sex profile of the group. Comparing the actual frequencies with the expected frequencies allows the group to identify areas where a gender imbalance may be occurring. Note that the expected frequencies need not be integer values (e.g., Expected count of Female Decision Makers is 3.1) as they are strictly a mathematical calculation.

\section{Instructions:}

1) Enter the name/identifier of each Group member in the column labeled Name

2) There is room for up to 50 members of your group

If your group is larger than 50 please contact the BWA

they will reconfigure the Baseline-Data sheet to accommodate your group size

3) Enter the sex of each Group member in the column labeled Sex

There are 3 valid responses male, female or "blank"

4) For each entry in the Name column answer the six questions posed at the top of the column.

For example Column 3 asks "Is this person a Female-Dec. Maker?"

There are 3 valid responses yes, no or "blank"

Two examples (in Red) are included

Mrs. Webster is Female, a Female-Dec. Maker, a Female-Policy Dev and a Female-

Proj. Mgr.

resulting in the entry: Mrs. Webster female yes no yes no yes no

Fred Spiring is Male, not a Male-Dec. Maker, not a Male-Policy Dev and not a Male-

Proj. Mgr.

resulting in the entry: Fred Spiring male no no no no no no

5) All the counts and plots should update as you enter the data

Very few of the cells in the Baseline-data sheet are locked and can be altered

If something looks funny or if the Baseline-Data sheet goes awry, DO NOT WORRY

Contact the BWA, they can send another copy to you electronically

Be sure to "save" your data frequently

6) Please let the BWA know if you have any difficulties or encounter problems

Bureau of Women's Affairs

voice: $754-8576$

fax: 929-0549

Figure 9. Associated Instructions for Gender Assessment

\begin{tabular}{|c|c|c|c|c|c|c|c|}
\hline & \multirow{2}{*}{\begin{tabular}{|c} 
Is this \\
person \\
a \\
Female- \\
Dec. \\
Maker? \\
\end{tabular}} & \multirow{2}{*}{$\begin{array}{c}\text { Is this } \\
\text { person } \\
\text { a } \\
\text { Male- } \\
\text { Dec. } \\
\text { Maker? }\end{array}$} & \multirow{2}{*}{$\begin{array}{c}\text { Is this } \\
\text { person a } \\
\text { Female- } \\
\text { Policy } \\
\text { Dev.? }\end{array}$} & \multirow{2}{*}{$\begin{array}{c}\text { Is this } \\
\text { person } \\
\text { a } \\
\text { Male- } \\
\text { Policy } \\
\text { Dev? }\end{array}$} & \multirow{2}{*}{$\begin{array}{l}\text { Is this } \\
\text { person a } \\
\text { Female- } \\
\text { Proj. } \\
\text { Manager? }\end{array}$} & \multirow{2}{*}{$\begin{array}{c}\text { Is this } \\
\text { person a } \\
\text { Male- } \\
\text { Proj. } \\
\text { Manager? }\end{array}$} \\
\hline Name & Sex & & & & & & \\
\hline Mrs. Webster & female & yes & no & yes & no & yes & no \\
\hline Fred Spiring & male & no & no & no & no & no & no \\
\hline Employee \#1 & female & yes & no & yes & no & yes & no \\
\hline Employee \#2 & female & no & no & no & no & no & no \\
\hline Employee \#3 & female & yes & no & yes & no & yes & no \\
\hline Employee \#4 & female & no & no & yes & no & yes & no \\
\hline Employee \#5 & female & no & no & no & no & no & no \\
\hline Employee \#6 & female & no & no & no & no & no & no \\
\hline Employee \#7 & female & no & no & no & no & no & no \\
\hline Employee \#8 & male & no & yes & no & yes & no & yes \\
\hline Employee \#9 & female & yes & no & yes & no & yes & no \\
\hline
\end{tabular}


Spiring, F. (2015). Introducting Statistics within a Gender Focal Point Strategy. Advances in Social Sciences Research Journal, 2(4) $171-197$.

\begin{tabular}{|l|c|c|c|c|c|c|c|} 
Employee \#10 & female & no & no & yes & no & no & no \\
\hline Employee \#11 & female & no & no & no & no & yes & no \\
\hline Employee \#12 & female & no & no & no & no & yes & no \\
\hline Employee \#13 & female & no & no & yes & no & yes & no \\
\hline Employee \#14 & female & no & no & yes & no & no & no \\
\hline Employee \#15 & male & no & no & no & no & no & yes \\
\hline Employee \#16 & female & no & no & no & no & no & no \\
\hline Employee \#17 & female & no & no & no & no & no & no \\
\hline Employee \#18 & female & no & no & no & no & no & no \\
\hline Employee \#19 & female & no & no & no & no & no & no \\
\hline Employee \#20 & male & no & no & no & no & no & no \\
\hline Employee \#21 & male & no & no & no & no & no & no \\
\hline Employee \#22 & male & no & no & no & no & no & no \\
\hline & & & & & & & \\
\hline & & & & & & & \\
\hline & 17 & 3 & 1 & 7 & 1 & 7 & 22 \\
\hline $\begin{array}{l}\text { Eount } \\
\text { Total }\end{array}$ & 22 & 22 & 22 & 22 & 22 & 22 & 22 \\
\hline $\begin{array}{l}\text { Percentage } \\
\text { Expected Count }\end{array}$ & $77.3 \%$ & $13.6 \%$ & $4.5 \%$ & $31.8 \%$ & $4.5 \%$ & $31.8 \%$ & $9.1 \%$ \\
\hline
\end{tabular}

Figure 10. Decision maker, Policy developer and Project manager Gender Assessment

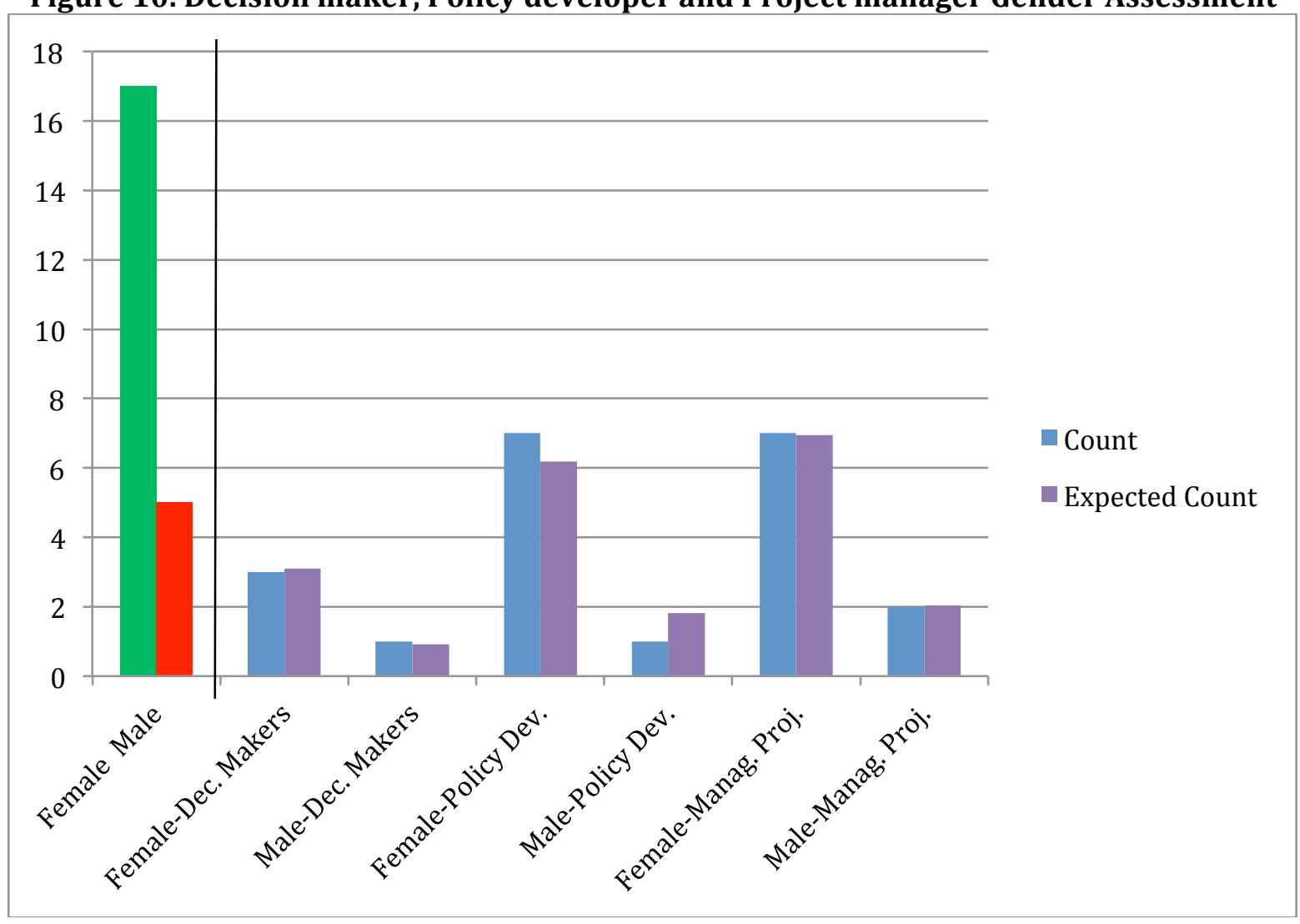


Figure 11. Decision maker, Policy developer and Project manager Gender Assessment A third and more formal assessment instrument has been developed in conjunction with the Self Start Fund, from the Ministry of Industry, Investment and Commerce, Government of Jamaica. It too is currently automated for up to 20 participants and addresses the individuals' assessment of their MDA or group. The current version of the questionnaire appears in Figure 13. The instrument is easily adaptable to different questions and/or more participants.

Figures 12,13, 14 \& 15 contain a) the instructions, b) the Questionnaire, c) the frequencies for sex, Questions 1 and 2 and d) the frequency summaries for the "Yes/No" responses respectively. In addition, the narrative responses to Questions 4 through 11 are captured in spread sheets for simpler review.

\section{Instructions:}

1) Randomly assign an unique number between 1-10 to each of your group members (e.g., Fred is assigned the number 6).

2) Ask each group member to complete the Questionnaire associated with their randomly assigned number (e.g., Fred to complete Questionnaire\#6)

3) There are 10 uniquely numbered questionnaires.

If you require more please contact the BWA

they will reconfigure the numbered questionnaires to accommodate your group size

4) Enter your responses in the various locations on your Questionnaire.

For Questions 1 through 8, the first portion of each question can be answered using a pull down menu

Question 1 allows responses Female, Male or "Blank"

Questions 2 \& 3 allow responses Low, Medium, High or "Blank"

Questions 4 through 8 allowable responses include Yes, No, or "Blank"

You can add your comments associated with questions 4-8 in the Comments section

as well as your written responses to Questions 9-11 in the associated boxes.

Note that no summaries of the written responses are summarized. If saved they will remain on the Questionnaire for reference.

Be sure to Save your responses.

5) The counts associated with Questions 1-8 and the resulting plots should update as you enter the data

Very few of the cells in the Excel sheets are locked and can be altered

If something looks funny or if the Datasheet goes awry, DO NOT WORRY

Contact the BWA, they can send another copy to you electronically

6) Please let the BWA know if you have any difficulties or encounter problems

Bureau of Women's Affairs

voice: $754-8576$

fax: 929-0549 
Figure 12. The Instructions for using the Questionnaire

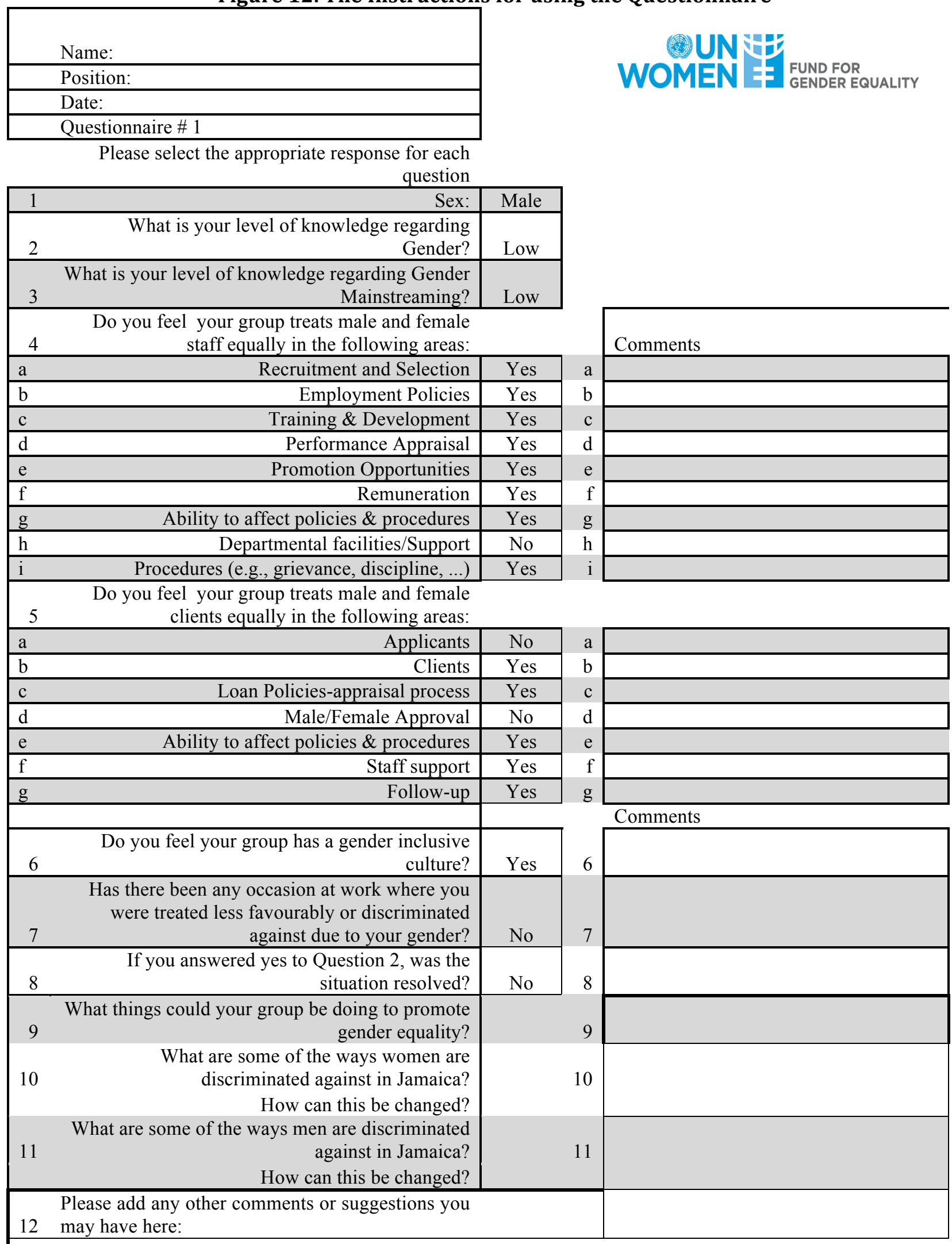


Figure 13. The Questionnaire

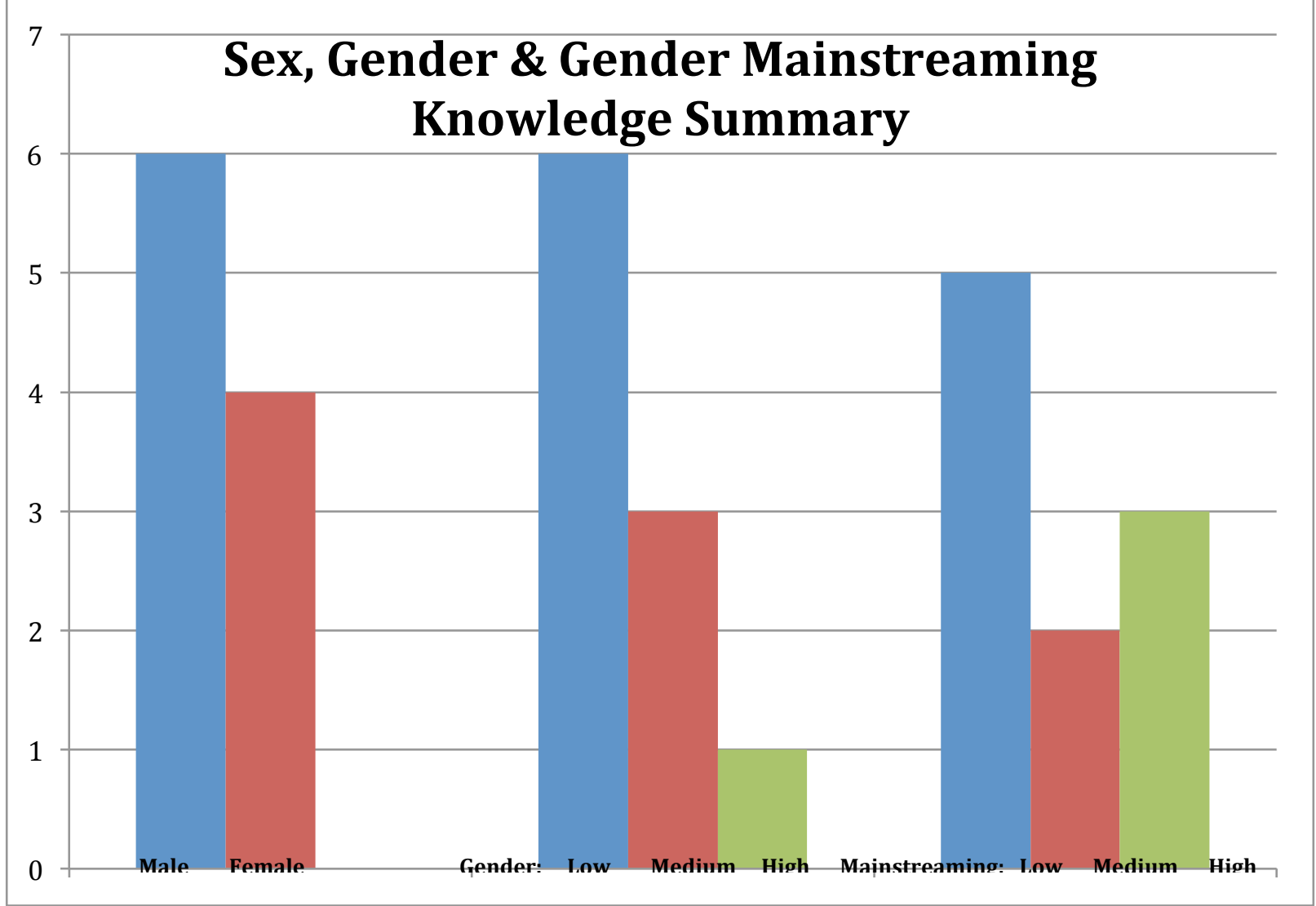

Figure 14. Frequency chart for Questions $2 \& 3$

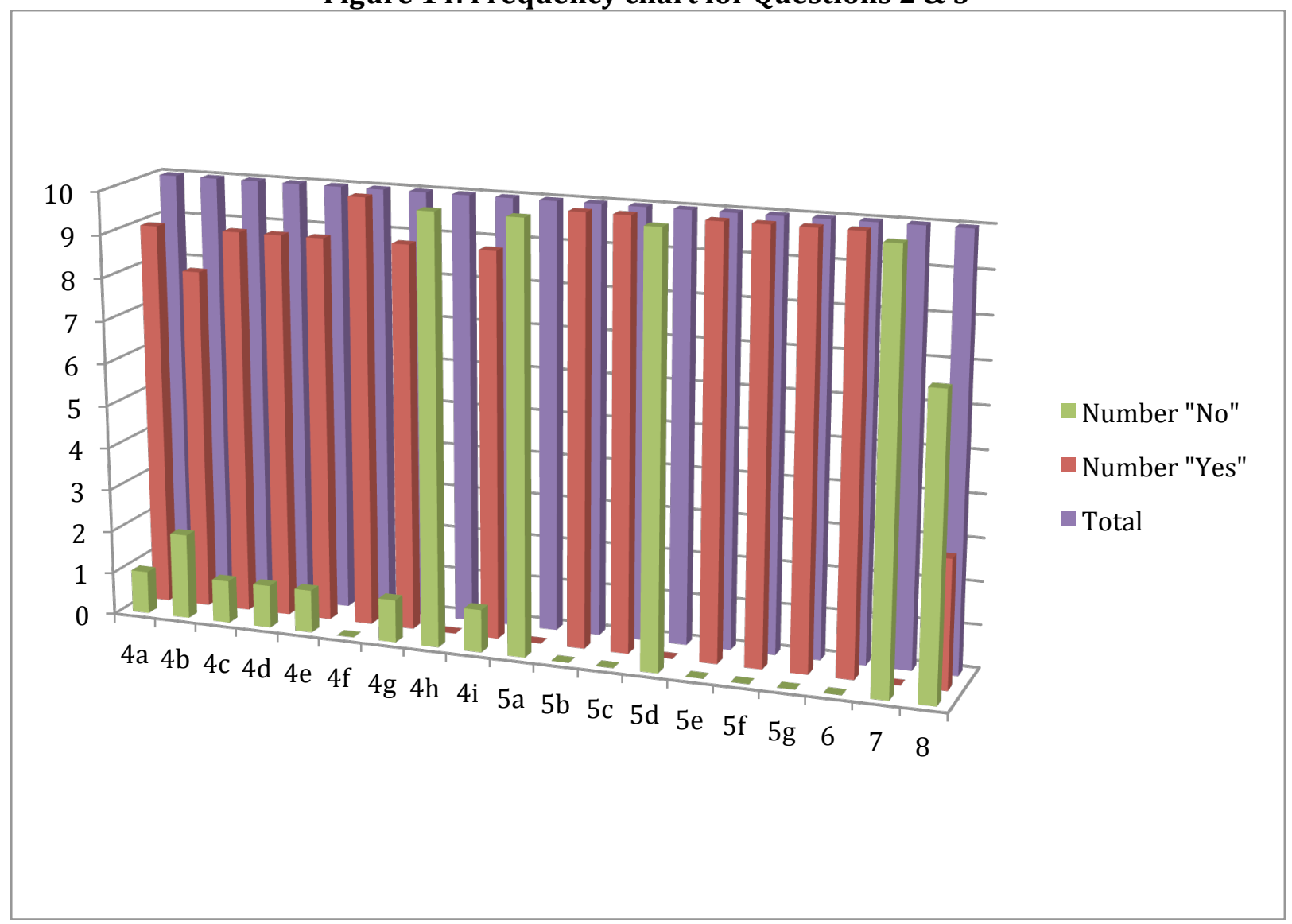




\title{
Figure 15. Frequency chart for Questions 4-8
}

These three instruments have been developed to assist individuals and groups initiate collecting and analyzing relevant data in a Gender Mainstreaming initiative. The initial application of any or all of these instruments would serve as a baseline assessment. Subsequent or repeated use of the instrument(s) could be used to examine changes and or trends in the level of gender \& gender mainstreaming knowledge, changes in the Decisionmaking structure of a group or organization and shifts in attitude with regards to gender and gender equality within a group or organization. All are easy to use and can be modified to reflect different group's requirements or needs. Electronic copies of these instruments are included in the training package and available from the Bureau of Women's Affairs, Office of the Prime Minister, Kingston, Jamaica. The instruments also provide examples used in DART Modules $1 \& 2$.

\section{DART Module 2}

\section{Bureau of Women's Affairs DART: Module 2}

\author{
WHAT DATA DO I NEED TO GATHER? \\ DEFINE THE GOALS OF THE STUDY/PROJECT \\ DEVELOP AN INSTRUMENT THAT ADDRESSES \\ GOALS \\ IDENTIFY THE GROUP(S) OF INTEREST \\ INVESTIGATE INFLUENTIAL FACTORS \\ -DOCUMENT RELEVANT DEFINITIONS \\ •CONSIDER A TRIAL OR TEST STUDY
}

DART Module 2 "What Data do I need to gather?" is designed to raise questions regarding the goals of the study or project and to address factors and issues that may impact the outcomes/results of the study. Participants are taken through an exercise illustrating some of the pitfalls associated with attempting to assess the quality of "a Cookie". A planning document outlining the actions, activities, participants, timeline and results that addresses issues that one should consider while developing an instrument is illustrated in Figure 16. Examples/analogies of the expected outcomes are drawn from the "Quality of a Cookie" exercise.

The "Quality of a Cookie" exercise is followed by a brainstorming session designed to acquire information/data in support of a gender based performance Indicator. The module currently uses a performance indicator from Jamaica's Vision 2030 Gender matrix, but is easily substituted for in the case of a different audience. For example a brainstorming session to examine a Friend of the Chair's Violence Indicator could be conducted. 


\begin{tabular}{|c|c|c|c|c|}
\hline $\begin{array}{l}\text { ACTION } \\
\text { ITEM }\end{array}$ & $\begin{array}{l}\text { ACTIVITIES/ } \\
\text { RESOURCES }\end{array}$ & WHO & WHEN & $\begin{array}{l}\text { EXPECTED } \\
\text { OUTCOMES }\end{array}$ \\
\hline $\begin{array}{l}\text { Identify } \\
\text { potential goals } \\
\text { of the project }\end{array}$ & 1. Brainstorm & $\begin{array}{ll}\text { 1.All } & \text { stake } \\
\text { holders } & \end{array}$ & $\begin{array}{llr}1 . & \text { Before } & \text { any } \\
\text { actions or data } \\
\text { collection } \\
\text { place }\end{array}$ & $\begin{array}{l}\text { 1. A list of potential goals or } \\
\text { objectives to be addressed by } \\
\text { the project }\end{array}$ \\
\hline $\begin{array}{l}\text { Prioritize the } \\
\text { list }\end{array}$ & $\begin{array}{ll}\text { 1. } & \text { Brainstorm } \\
\text { 2. } & \text { Planning } \\
& \text { Document }\end{array}$ & $\begin{array}{ll}\text { 1.All } & \text { stake } \\
\text { holders } & \end{array}$ & $\begin{array}{llr}1 . \quad \text { Before } & \text { any } \\
\text { actions or data } \\
\text { collection } \\
\text { place }\end{array}$ & $\begin{array}{l}\text { 1. A finalized list of goals or } \\
\text { objectives to be addressed by } \\
\text { the project }\end{array}$ \\
\hline $\begin{array}{l}\text { Develop an } \\
\text { Instrument }\end{array}$ & 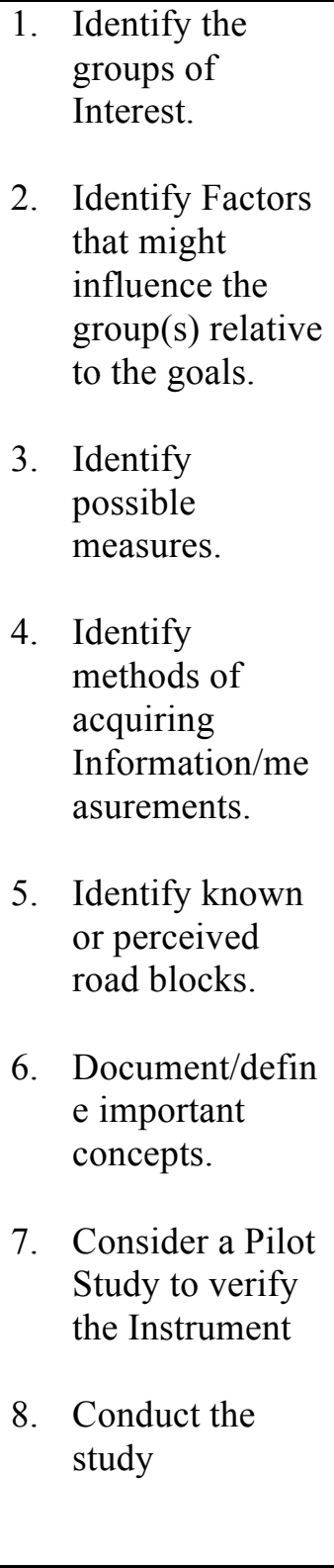 & $\begin{array}{l}\text { 1-7.All stake } \\
\text { holders } \\
\text { 8. Instrument } \\
\text { delivery vehicle }\end{array}$ & $\begin{array}{l}\text { 1-7. Planning stage } \\
\text { 8. Study stage }\end{array}$ & $\begin{array}{l}\text { 1.List of units to be sampled } \\
\text { from (e.g., Residents of } \\
\text { Jamaica) } \\
\text { 2. List of Influences that need } \\
\text { to be considered when } \\
\text { investigating (e.g., sex, age, } \\
\text { urban/rural, number of } \\
\text { children < 12, } \\
\text { 3. Clearly delineated what is } \\
\text { to be measured (e.g., number } \\
\text { of cookies, taste, } \\
\text {...) } \\
\text { 4. Fully developed selection } \\
\text { scheme (e.g., randomly collect } \\
\text { from population, collect all } \\
\text { from participants, } \\
\text { 5. List of impediments to the } \\
\text { data collection and/or } \\
\text { measuring schemes (e.g., } \\
\text { varying sense of taste, broken } \\
\text { cookies, } \\
\text { 6. Carefully documented key } \\
\text { parts of the study (e.g., count } \\
\text { only whole cookies that are } \\
\text { identifiable as animals, ...) } \\
\text { 7. Conduct a Pilot study (e.g., } \\
\text { use the Trainers to assess the } \\
\text { Instrument before applying to } \\
\text { the GFs, } \\
\text { 8. Conduct the study }\end{array}$ \\
\hline
\end{tabular}




\section{DART Module 3}

\section{Figure 16. Instrument Planning Document}

\section{Bureau of Women's Affairs DART: Module 3}

\section{WHAT DOCUMENTATION DO I NEED?}

\section{- DATA DOCUMENTATION IS OFTEN REFERRED TO AS METADATA.}

- METADATA IS A FORMAL WAY OF DESCRIBING THE WHO, WHAT, WHEN, WHERE AND WHY OF YOUR PROJECT.

- IN PARTICULAR THE GOALS, INFORMATION, DATA AND TIMELINES SHOULD BE INCLUDED.

The BWA has adopted the International Household Survey Network's (IHSN) Metadata software Metadata Editor and Nesstar Explorer. The software is available on the web at www.ihsn.com, recommended by UNECLAC, reasonably easy to use and used around the globe. Module 3 has been designed to introduce the software using exercises investigated in Modules $1 \& 2$, in particular documenting the data for the Gnirips Shoe exercise from Module 1. Figure 17 contains the Study Description for the Gnirips Shoe Company Study and Figure 18 the Data View. A second example documents the results of the "quality of cookies" brainstorming session.

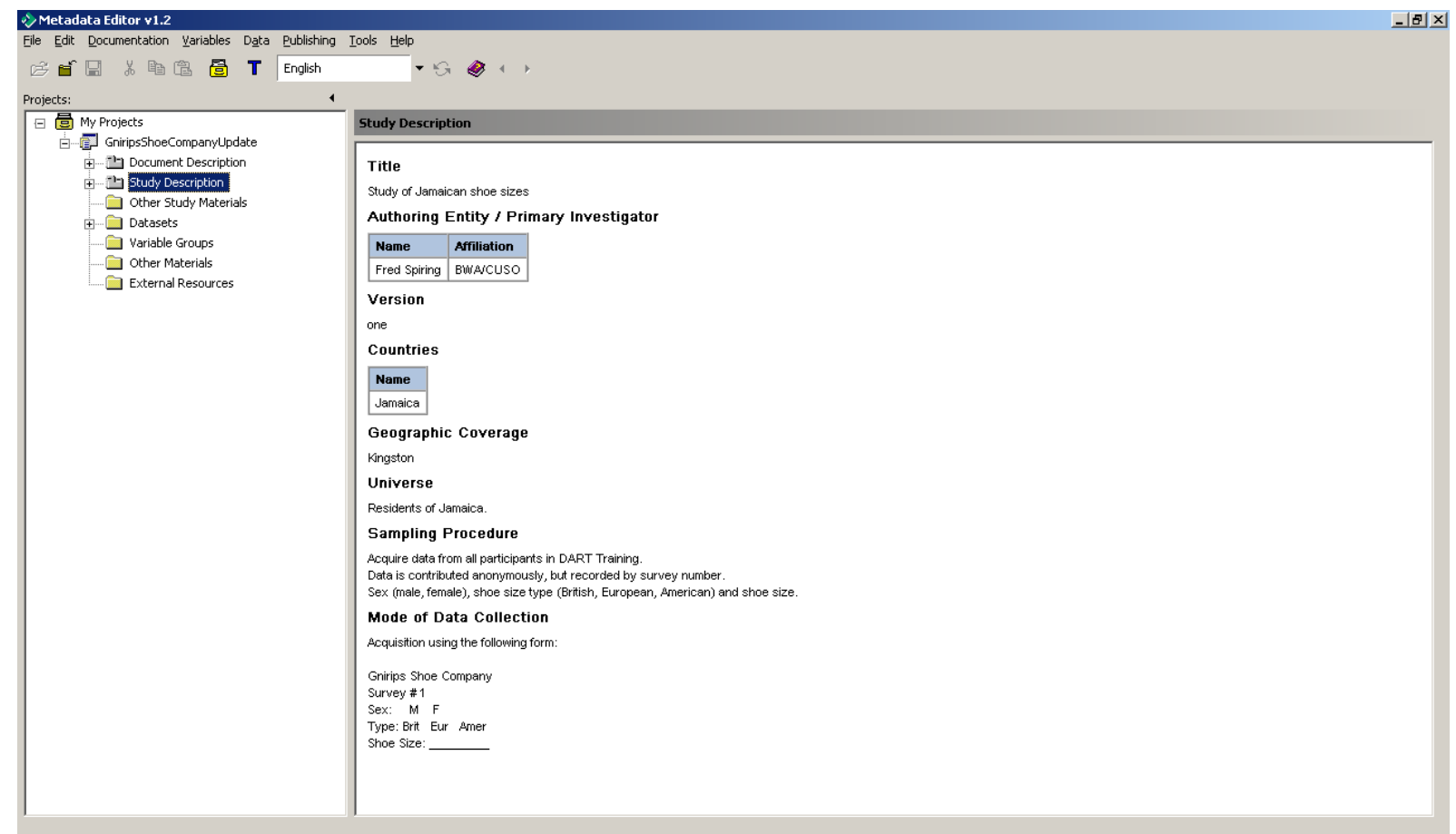

Figure 17. Metadata Editor's Study Description for Gnirips Shoe Company 


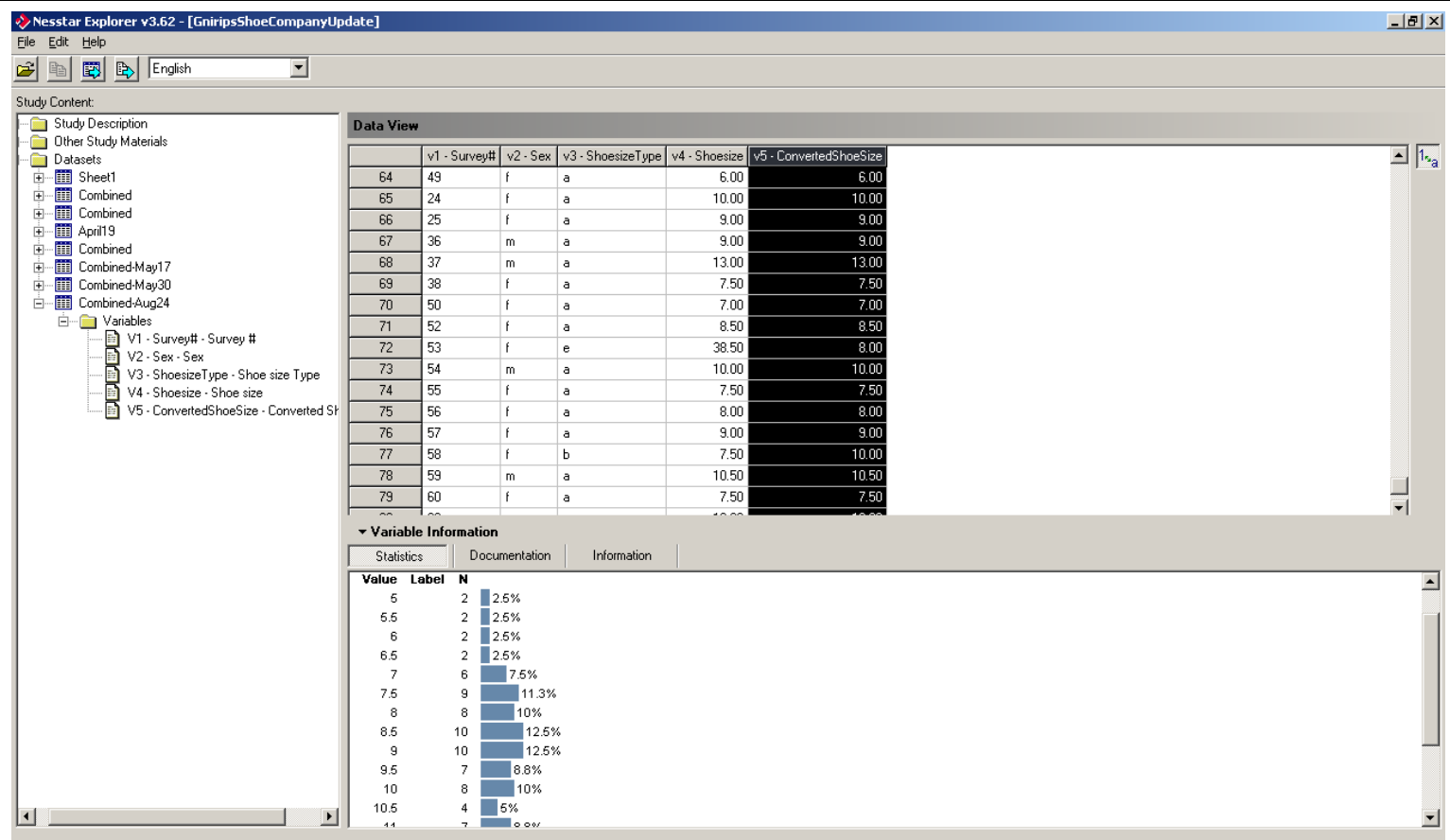

Figure 18. Nesstar Explorer's Data View for Gnirips Shoe Company

\section{DART Module 4}

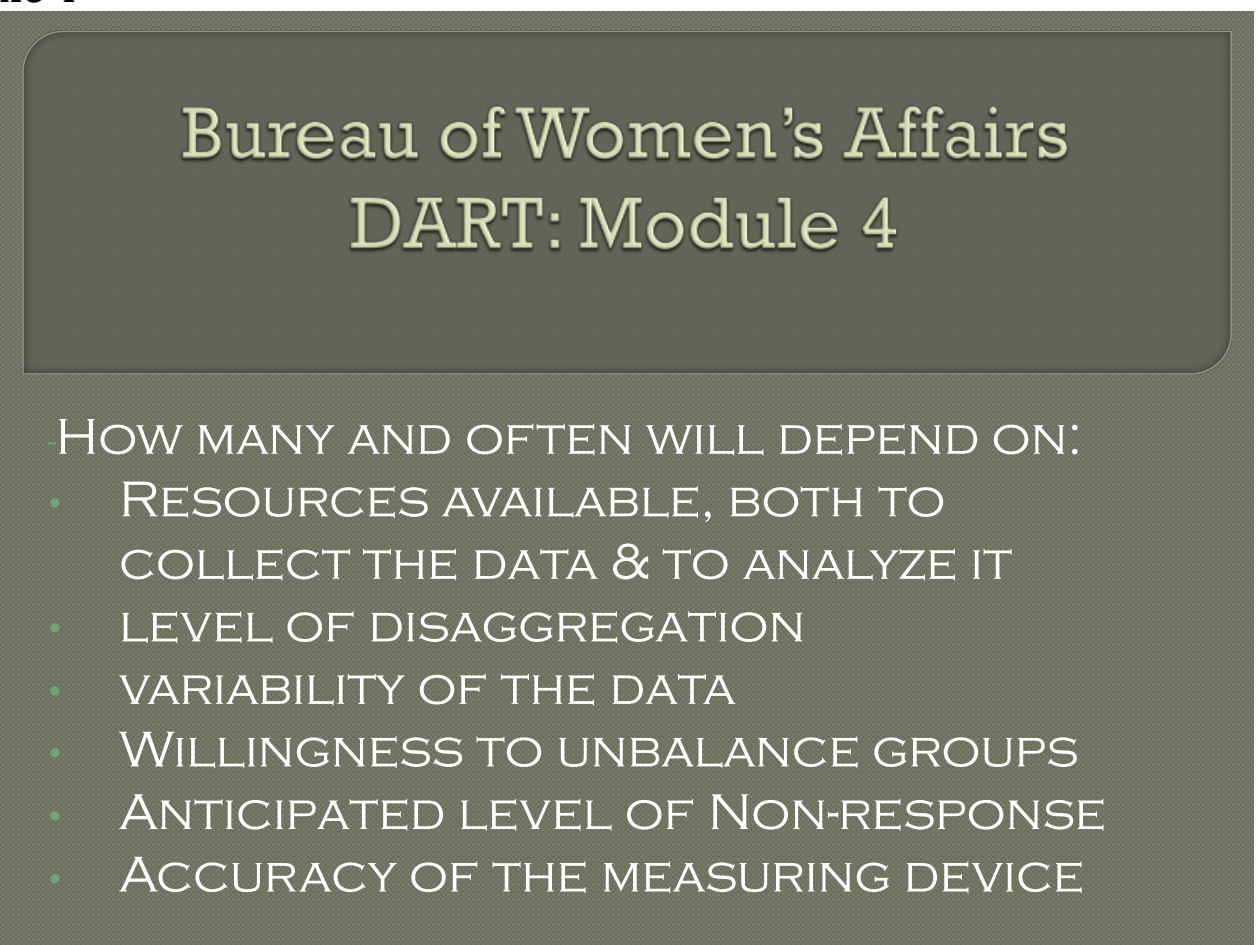

Module 4 continues the data acquisition theme common to Modules 1, 2 and 3 . In this Module the concept of how many and/or how often is investigated. Issues surrounding the determination of how many samples does one need are raised and set out as points that need to be addressed prior to initiating a data acquisition scheme. Similar to Module 2 the focus is on insuring the goals of the study are clearly delineated and are part of the acquisition discussion. An exercise developed to make one think about the actual measuring device(s) is incorporated into the Module. Issues including non-response and measurement error are raised for awareness and discussion. A gauge qualifying exercise is illustrated. The module 
concludes with a brainstorming session addressing an indicator from the Millennium Development Goals (MDG).

\title{
DART Module 5
}

\section{Bureau of Women's Affairs DART: Module 5}

\author{
PERFORMANCE INDICATOR \\ A PERFORMANCE INDICATOR (PI) IS A TYPE OF \\ PERFORMANCE MEASURE USUALLY TIED TO \\ SOME GOAL OR DESIRED OUTCOME. \\ PIS ARE COMMONLY USED BY ORGANIZATIONS \\ TO EVALUATE THEIR “SUCCESS” OR THE \\ "SUCCESS OF A PARTICULAR ACTIVITY" IN \\ WHICH THEY ARE ENGAGED.
}

Module 5 signals a change in direction, moving from data acquisition issues and concepts to using data to address the goals of the study or project. Various gender related performance indicators are examined. The development of the Gender Equality Observatory of Jamaica (GEOJ) provides several opportunities to introduce Performance Indicators and to illustrate the need to have a baseline set of measures in order to monitor over time, while developing long term tracking tools to signal change. A portion of the Module is dedicated to illustrating Excel plotting techniques. Some basic statistics including trend lines are introduced (see Figure 19).

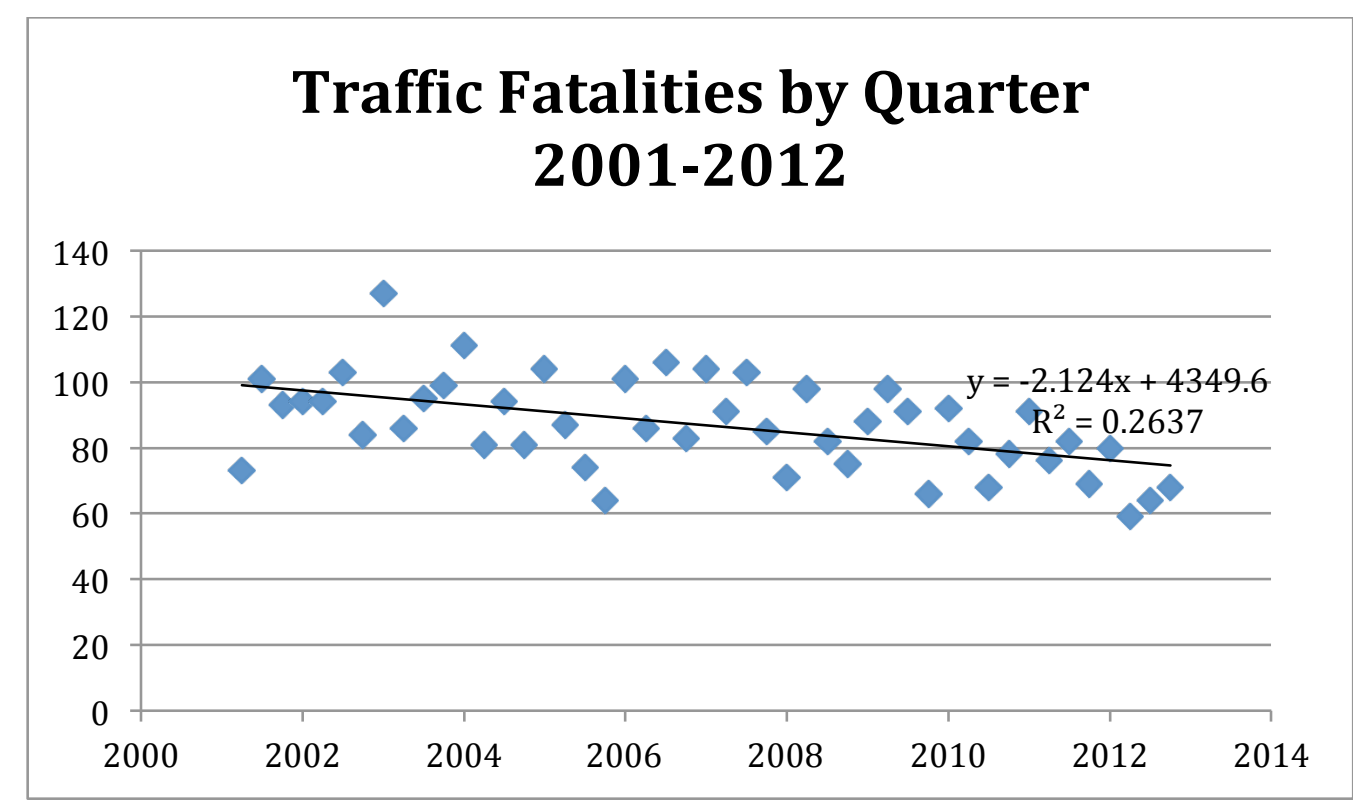

Figure 19. Excel Scatter plot with Trend line for Traffic Fatalities 


\section{DART Module 6}

\section{Bureau of Women's Affairs DART: Module 6}

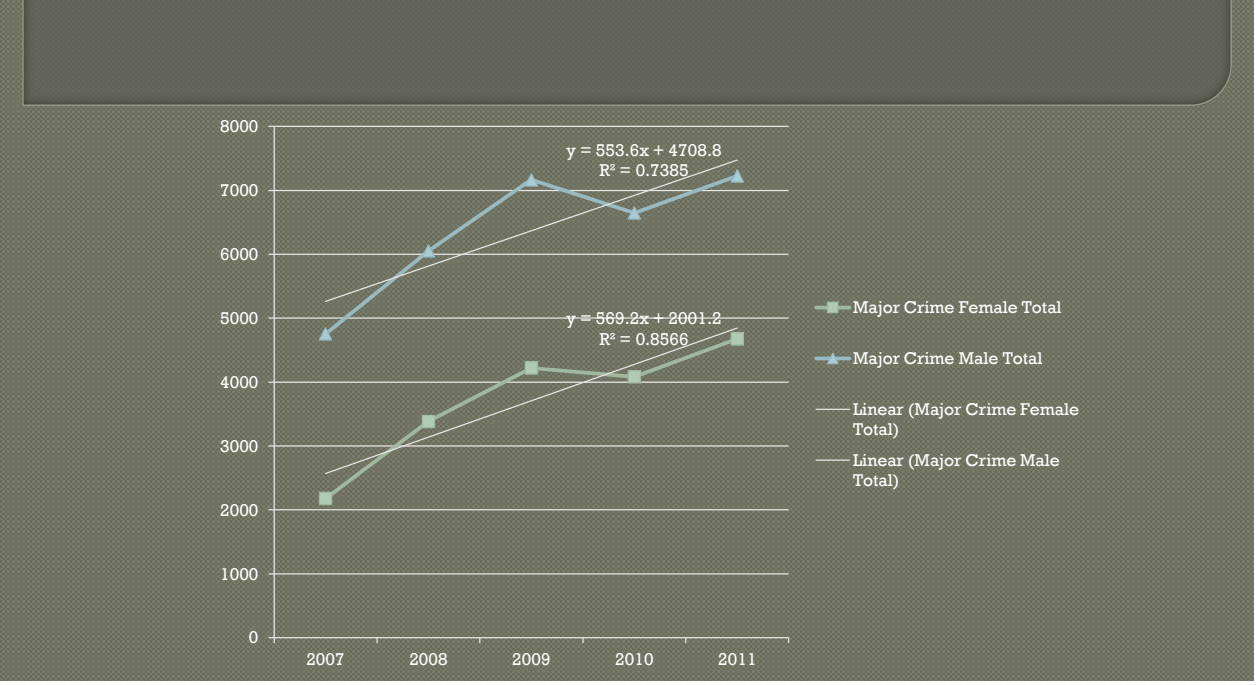

Module 6 continues along with the introduction of statistical techniques initiated in Module 5. The software package JMP IN is introduced in order to provide analytical statistical tools. The Gender Equality Observatory of Jamaica (GEOJ) again provides several Performance Indicators that are used to illustrate the need to have a baseline set of measures and how to monitor them over time. A portion of the Module is again dedicated to illustrating Excel [1] plotting techniques as well as JMP IN [4] plotting and analytical features. Some basic statistics are introduced. Examples include using JMP IN to analyze and create charts similar to those illustrated Figure 20.
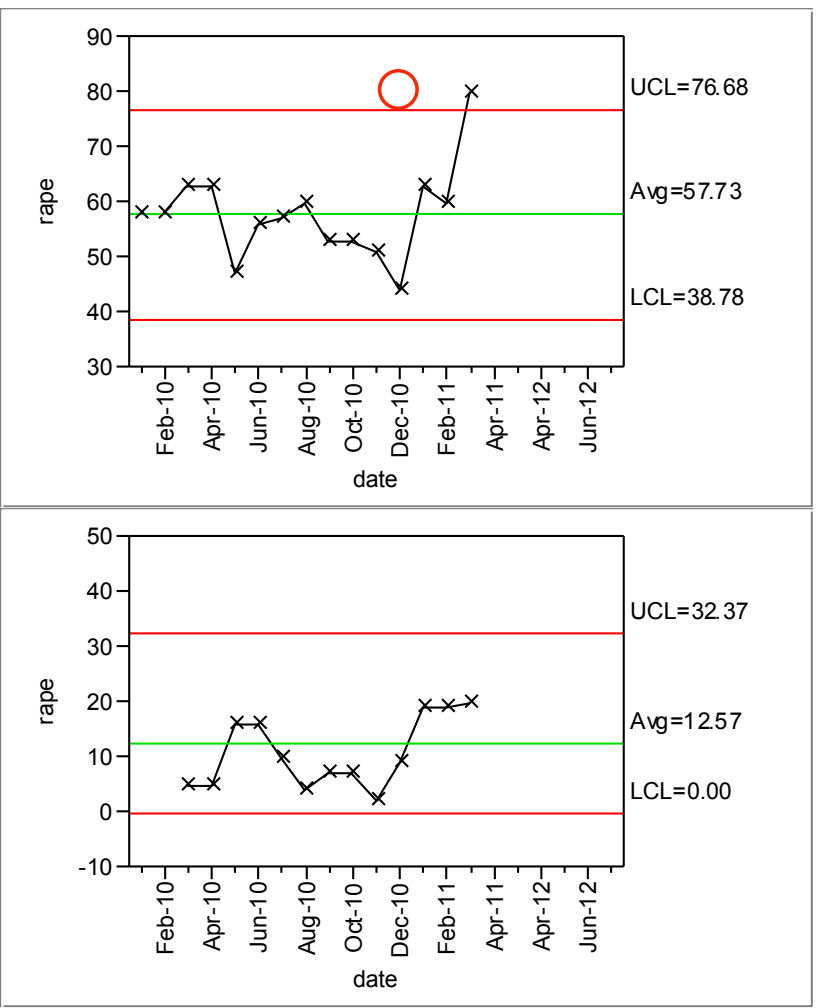

Figure 20. Individual \& Moving Range Chart of Monthly Rapes 


\section{DART Modules 7, 8, 9 \& 10}

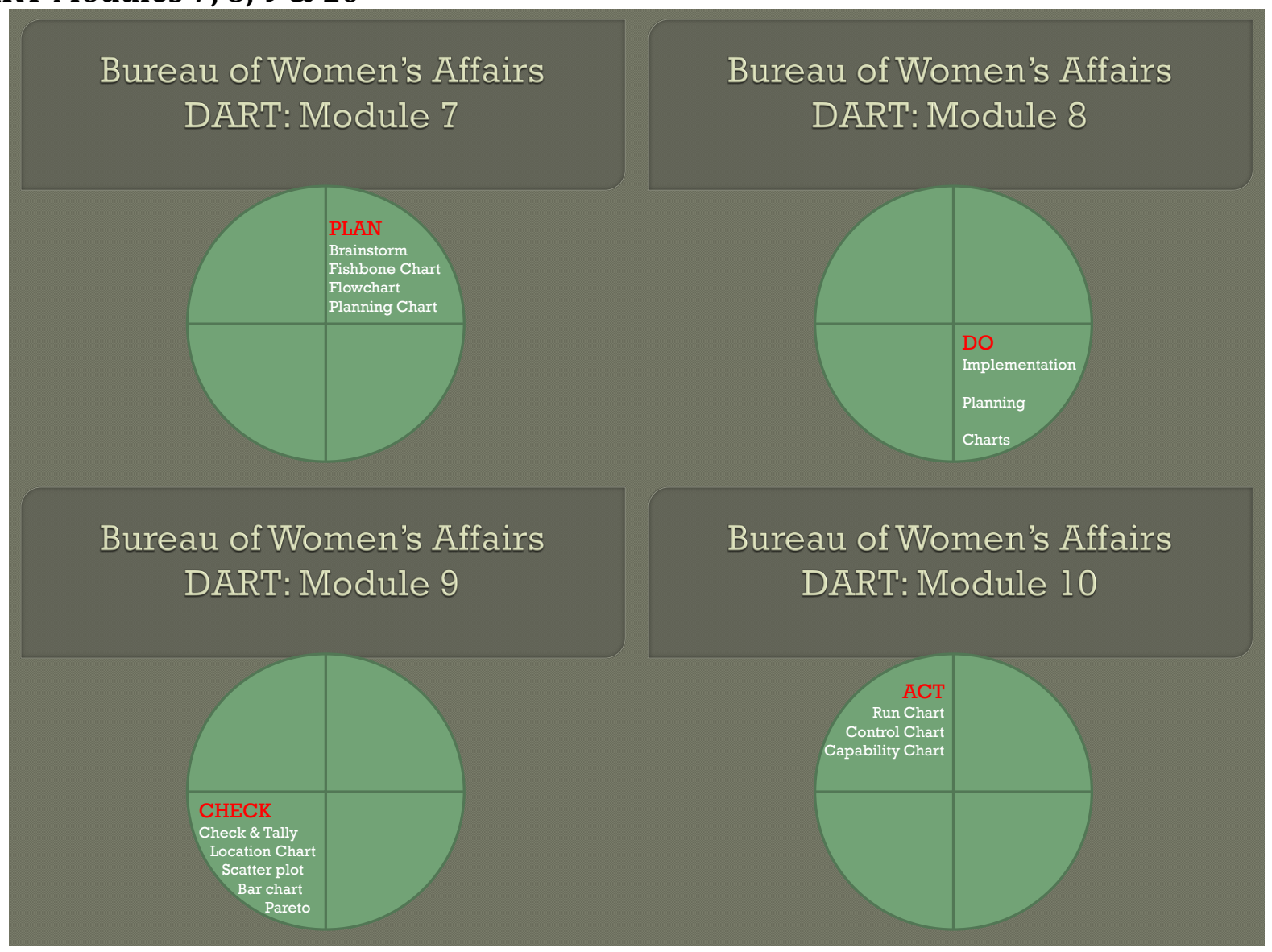

The United Nations Development Strategy for Gender in Development Programme refers to it as the PLANNING AND REVIEW CYCLES IMPLEMENTATION while the Quality Management/Process Improvement groups who use this problem solving technique refer to it as the Plan-Do-Check-Act (PDCA) cycle. The PDCA cycle (see Figure 21) is a mechanism for planning, documenting, analyzing, implementing and verifying the impact of a plan or strategy. Modules 7-10 address the four components of the PDCA cycle and tie in tools that are used in each of the stages. Each Module outlines the key components of its associated portion of the PDCA cycle, introduces the associated tools and provides examples of its use, all with the goal of integrating the concepts of PDCA and statistics into a Gender Focal Point training regimen.

More specifically, Module 7 introduces the concept of a process, outlines the customer/supplier role in a process, and introduces Flow charts (see Figure 22), Brainstorming, C\&E charts (see Figure 23) and Planning charts (see Figure 24) as tools of the Plan stage while providing links to the DO stage. The training session includes a brainstorming session relevant to the group. Module 8 reinforces the PDCA concept and the customer/supplier role in a process, while illustrating the implementation of results from the Brainstorming, C\&E, Flow and Planning charts associated with the Plan session and discusses the Do stage as the implementation stage. Module 9 sees the introduction/review of the Check \& Tally sheets, bar/column charts, Pareto charts while discussing various scatter plots and location charts as tools of the Check stage in PDCA cycle. Module 10 introduces and reviews runs charts, control charts and capability charts by adding action limits to existing scatter and line plots. Module 10 also discusses the need to establish baseline measures in order to monitor indicators and develop long term tracking tools to signal change. Finally, as in a continuous improvement environment, Module 10 restarts the PDCA cycle. 


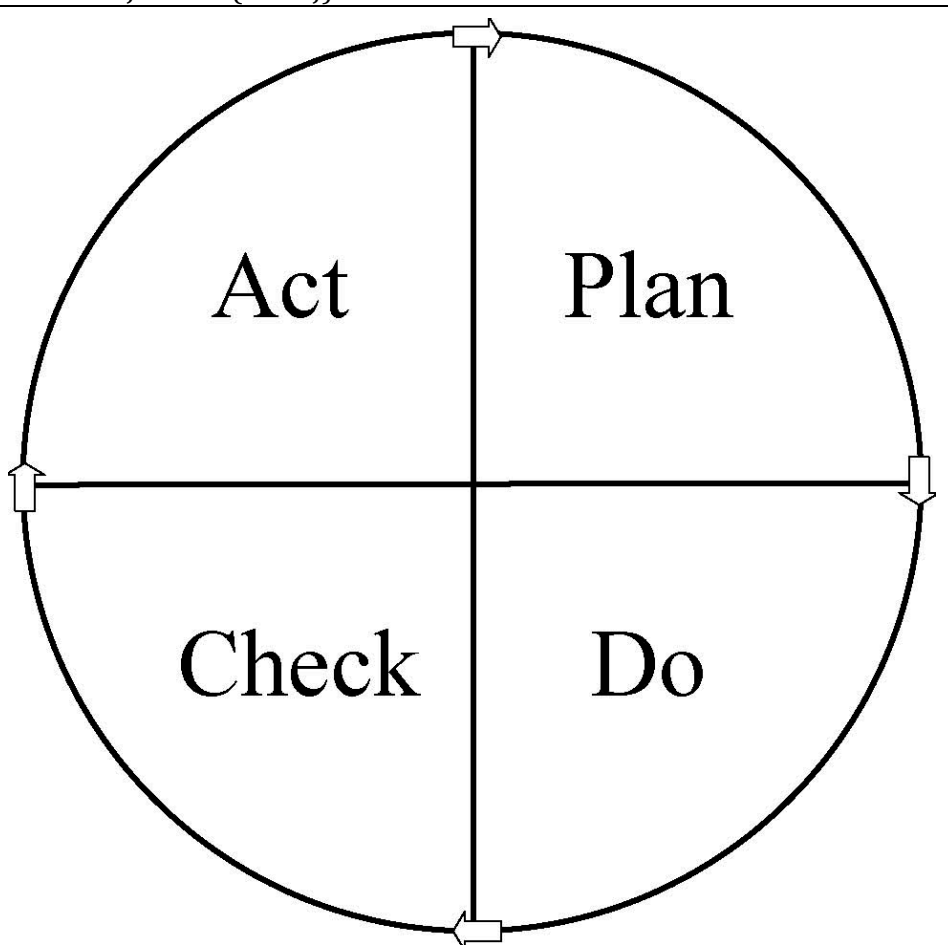

Figure 21. The Plan-Do-Check-Act cycle

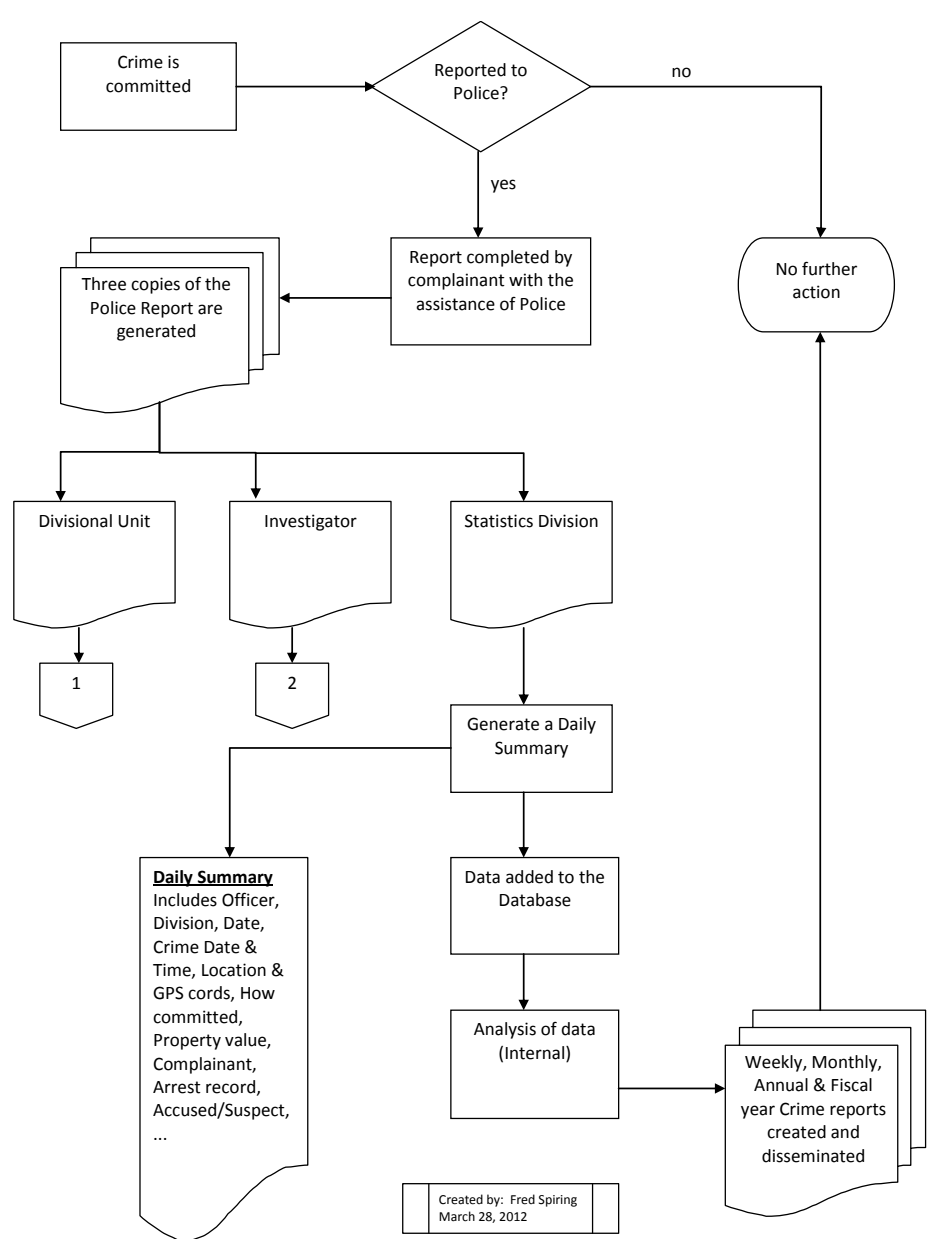

Figure 22. An Example of a Flowchart 


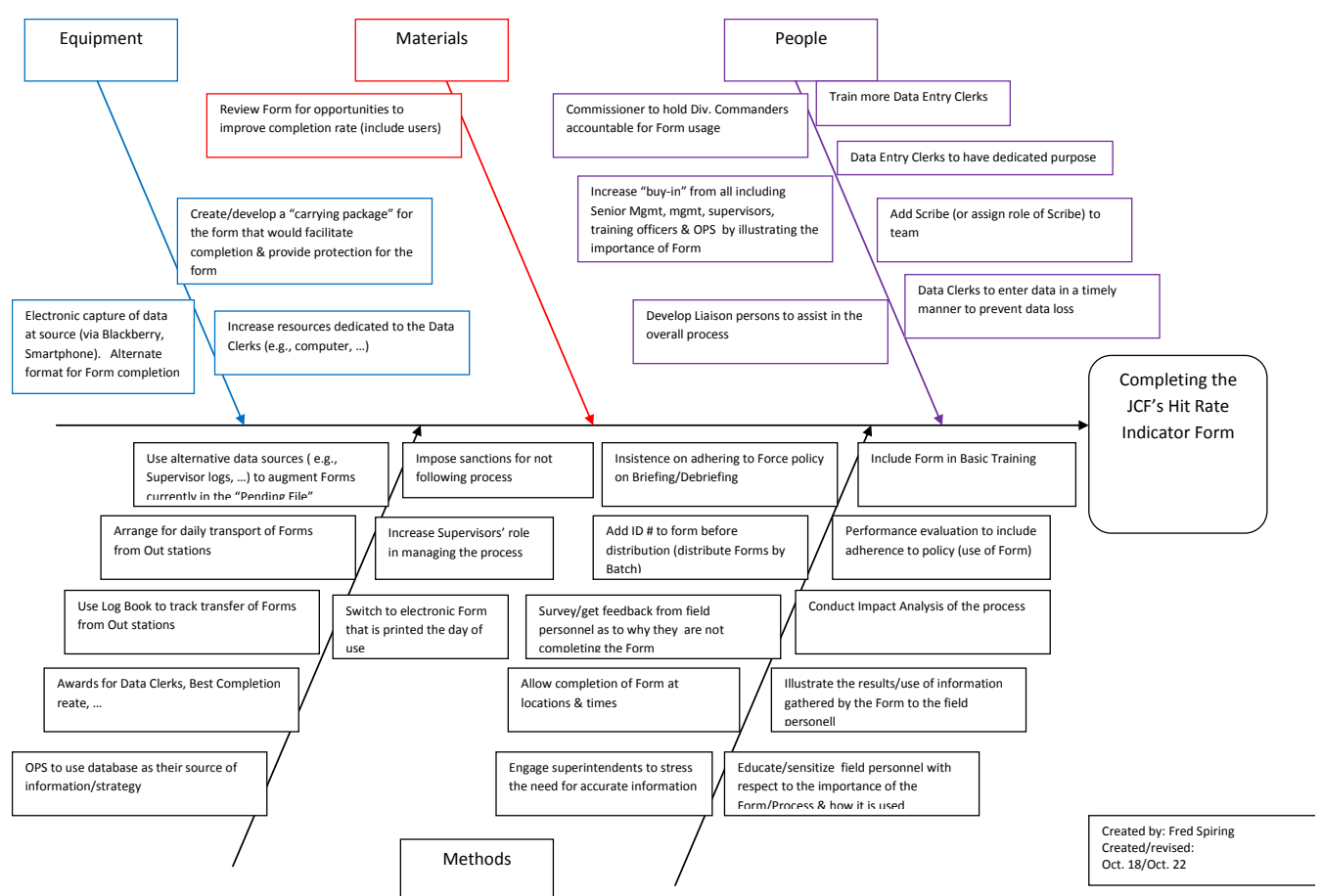

Figure 23. An Example of a Cause \& Effect chart

Planning Document

\begin{tabular}{|c|c|c|c|c|}
\hline ACTION ITEM & ACTIVITIES/RESOURCES & WHO & WHEN & EXPECTED OUTCOMES \\
\hline $\begin{array}{l}\text { Attendees } \\
\text { JCF DART Training } \\
\text { session October 18, } \\
2012\end{array}$ & $\begin{array}{l}\text { Sgt Bascoe, W/Sgt Brown, Cpl Wray, W/Cons } \\
\text { Campbell, W/Cons Williams, Insp Wint, D/nsp } \\
\text { Allen, Cons Melhoda, Cpl Dawkins, Sgt } \\
\text { Richards-Nicholson, Cpl Lee, Insp O'Connor, } \\
\text { Asst Supt Creary, Cons Tomlinson, Supt } \\
\text { Lawrence, Sgt McKenzie }\end{array}$ & $\begin{array}{l}\text { Supt Lawrence, Cpl } \\
\text { Lee to review } \\
\text { Attendee list for } \\
\text { completeness \& } \\
\text { spelling }\end{array}$ & By October 24 & \\
\hline Minntes & $\begin{array}{l}\text { 1. Review the following documents: } \\
\text { - Flowchart of Hit Rate Indicator } \\
\text {;. Cause \& fffect Chart } \\
\text { Planning Document-October 18, } 2012 . \\
\end{array}$ & \begin{tabular}{|l} 
1.All attendees \\
(Sgt Bascoe, Spiring) \\
(Spiring) \\
(Spiring) \\
\end{tabular} & $\begin{array}{l}\text { By October } 31 \\
\text { October } 24 \\
\text { October } 24 \\
\text { October } 24 \\
\end{array}$ & \\
\hline Taskl & $\begin{array}{l}\text { 1. Determine OPS timeline for completing } \\
\text { transition to New Form with identified } \\
\text { deadlines }\end{array}$ & $\begin{array}{l}\text { 1. Supt Lawrence, } \\
\text { Cpl Lee }\end{array}$ & 1. October 31 & 1. Update progress to the group \\
\hline Task2 2 & $\begin{array}{l}\text { 2. Determine OPS strategy \& timeline for using } \\
\text { database to drive strategy }\end{array}$ & $\begin{array}{l}\text { Supt Lawrence, } \\
\text { Cpl Lee }\end{array}$ & . October 31 & 2 Update progress to the group \\
\hline Task3 & $\begin{array}{l}\text { 3. Arrange to have Hit Rate Indicator included } \\
\text { in Basic Training }\end{array}$ & $\begin{array}{l}\text { 3. Supt Lawrence, } \\
\text { Cpl Lee }\end{array}$ & . October 31 & 3. Update progress to the group \\
\hline Task 4 & $\begin{array}{l}\text { 4. Develop a Buy-In strategy that includes the } \\
\text { Commissioner and using Kingston Central as } \\
\text { an example }\end{array}$ & $\begin{array}{l}\text { 1. Supt Lawrence, } \\
\text { Cpl Lee }\end{array}$ & 1. October 31 & 4 Update progress to the group \\
\hline Task 5 & $\begin{array}{l}\text { 5. Survey/Interview previous Trainers for } \\
\text { reasons why the Hit rate Indicator form Is not } \\
\text { being used }\end{array}$ & $\begin{array}{l}\text { Supt Lawrence, } \\
\text { Cpl Lee }\end{array}$ & F. October 31 & 5. Update progress to the group \\
\hline Next meeting & $\begin{array}{l}\text { How will you know if there has been improvement } \\
\text { in the Hit Rate Indicatior Process? }\end{array}$ & All attendees & October 31 & \\
\hline
\end{tabular}

Plenning Document, Version 1 Created By: Fred Spiring Created/Revised: April 3, 2012/April 5, 2012

Burean of Women's Affairs

Figure 24. An Example of a Planning chart

\section{IMPLEMENTATION}

The 10 training Modules have been designed to be delivered either in a series of ten 2 hour (or shorter) sessions or a two day (e.g., 9am-12noon, 1pm-5pm) style format. In either case, 
ample time for questions and discussion has been built into the timing. The Modules were developed to accompany a gender/gender mainstreaming training regimen, but can be delivered as stand alone. They can be easily used as an overview of statistics from a gender perspective. The 10 PowerPoint presentations, related datasets, questionnaires and supporting material are available electronically.

"Train the Trainer" sessions for Modules 1-6 take a slightly different approach, focusing on content, delivery and understanding with an initial one day session (8:30am - 12noon, 1:00pm to $5 \mathrm{pm}$ ) being sufficient to prepare Trainers. The BWA offers the "Modules" and "Train the Trainer" training to all Gender Focal Points and their respective Ministries, Departments and Agencies of the Jamaican Government. The PowerPoint presentations, related datasets, questionnaires and supporting material are available from the author.

\section{References}

The United Nations Development Strategy for Gender in Development Programme, "LEARNING \& INFORMATION PACK". September, 2000.

Microsoft Office 2007. Microsoft Corporation.

National Policy for Gender Equality, 2011. ISBN 978-976-610-931-8, The Bureau of Women's Affairs, Kingston, Jamaica.

JMP IN, Statistical Discovery Software. ISBN: 0-534-35966-3, SAS Institute Inc. 